\title{
The Development of the Prootic Head Somites and Eye Muscles in Chelydra Serpentina
}

A thesis submitted to the faculty of the Graduate School of the University of Minnesota, in partial fulfilment of the requirements for the degree of Doctor of Philosophy, June, 1912

BY

CHARLES EUGENE JOHNSON

Reprinted from The American Jourixar of instionty,

Vol. 14, No. 2, Janưriry', '1913 
Reprinted from The Amrrican Journal of ANatomy, Vol. 14, No. 2,

January, 1913

\section{THE DEVELOPMENT OF THE PROOTIC HEAD SOMITES AND EYE MUSCLES IN CHELYDRA SERPENTINA}

\section{CHARLES EUGENE JOHNSON}

From the Laboratory of Comparative Anatomy of Vertebrates, Department of Animal Biology, University of Minnesota

TWENTY-FOUR FIGURES (TEN PLATES)

\section{CONTENTS}

Introduction . ...

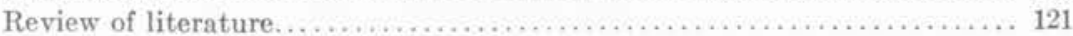

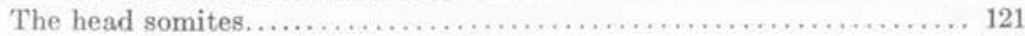

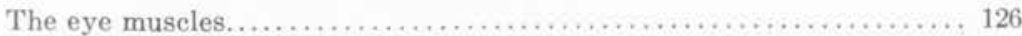

Descriptive part: material and methods.......................... 128

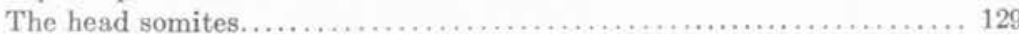

$3.5-m m$. embryo.................................... 129

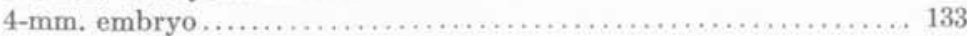

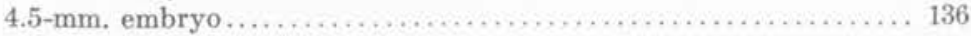

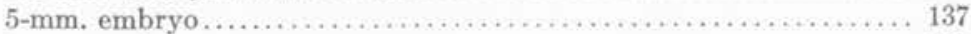

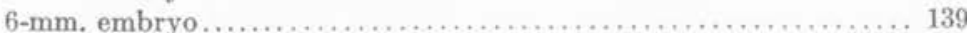

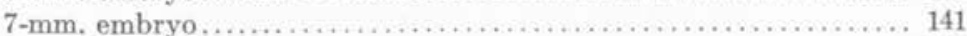

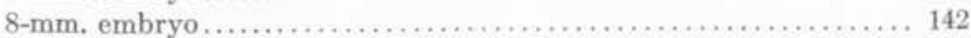

Summary ........................................ 143

The development of the eye museles....................... 144

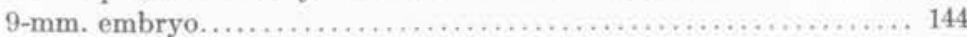

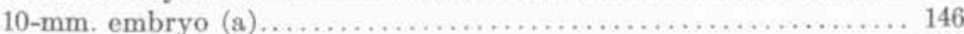

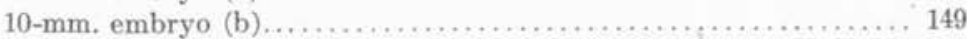

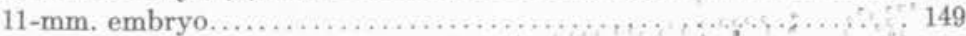

Chelydra embryo..............

Summary.....................

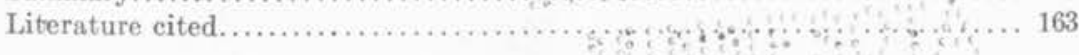

\section{INTRODUCTIÓN}

Balfour ('78), working on elasmobrancli embryos, was the first to observe that the separation of the mesodermic layers which gives rise to the body cavity of the trunk, extends forward into the head, and forms a cavity which later becomes

THE AMERICAN JOURNAL OF ANATOMY, VOL. 14 , NO. 2 JANUARY, 1913 
divided into a number of segments, called by him head cavities. These head cavities, later looked upon as true somites, became, as is well known, of considerable importance in connection with the question of the original segmentation of the vertebrate head.

The bulk of the work on the head cavities has been done on fishes, especially elasmobranch embryos, and a varying number of such cavities has been found in different members of the group, nine being probably the average. The head cavities or somites lying in front of the otic region have furnished the greater interest, as here evidence of segmentation has been effaced to a greater degree than in the opisthotic region, where cranial nerves of the vagus group, well differentiated somites, and the arterial and gill arches have been considered by investigators as strong evidence of metamerism. The scarcity of metameric evidence in the prootic region is associated with the progressive development of the brain and associated sense organs, so that the higher we.proceed in the vertebrate series the more obscure become the traces of any metamerism which may have existed in the precursors of the group.

The problem of the head somites in the Amphibia has received little attention, although Scott and Osborn as early as 1879 found that a portion of the coelom was present in the head and became segmented by the development of gill clefts; and Miss Platt ('94) found somites in Necturus corresponding to the prootic somites of elasmobranchs. In the Mammalia no head cavities can be said to have been found, although Zimmermann ('99), for a human embryo of $3.4 \mathrm{~mm}$., has described a number of small but clear-cut vesicles which may have been vestiges of such struptures For reptifles and birds on the other hand, cavities or somites corresponding to the first three head somites of elasmobranchs have been established. These eavities or somites accord with the prootic 'somites of the latter group in that they occupy correspondirg pesién in the mesoderm, have corresponding nerve relations, and in 'each case give rise to corresponding muscles of the eye-ball. But whether a particular somite in one class of vertebrates is strictly homologous with a particular somite in another group, is of course uncertain. 
To morphologists looking to the problem of the segmentation of the vertebrate head, the important question is whether these so-called head somites or cavities represent true somites, comparable to the somites of the trunk and occipital regions, and are therefore marks of a primitive segmentation of the head. The answer to this naturally depends upon each investigator's individual conception of what constitutes a true somite; and, as Filatoff ('07) has pointed out in this connection, the variability of a somite in the head region of higher vertebrates, due to the disturbing influence of a greater development in brain and sense organs, must be taken into consideration. Some forms, for instance, may be so highly specialized that all the characteristics of a typical somite have dropped out. As will be noted in the review of literature, the question has been answered in the affirmative by investigators of the head cavities in the Reptilia. For the Aves, Rex ('05), from extensive studies on this group, believes that these structures are products of the visceral mesoderm, and hence cannot be considered true somites, which are differentiations of the dorsal, or paraxial, mesoderm only.

\section{REVIEW OF LITERATURE}

\section{THE HEAD SOMTTES}

The first observations on the head somites of the Reptilia were made by Van Wijhe ('86). This author, in embryos of Lacerta, found what he considered to be the homologue of the first head somite of selachians, in the form of a large sac the, wall of which consists of a single layer of celis, lying: on" each'side close to the posterior surface of the optic vesicle. There, was no connection between the cavities of thesc.tworsaes. Becsuse of their position, their association witt tine veulomotor nerve, and the later transformation of parts of their.watls into the same eye muscles that arise from the first head somite in selachians, Van Wijhe declared them homologous structures.

In regard to a second head somite in reptiles, Van Wijhe makes no mention. 
At a place corresponding precisely to the position in which the third head somite of selachians is situated, Van Wijhe found a solid mass of cells formed from indifferent embryonic mesoderm, which grows forward, becomes associated with the abducent nerve, and gives rise to the Musculus rectus lateralis. This cell-mass he accordingly calls the homologue of the third head somite of selachians.

Hoffmann ('88), also working on embryos of Lacerta, (L. agilis), found that at a stage in which the optic vesicles are being formed, the first head somites are rather small cavities, one on each side, the walls of which consist of a single layer of cells. These somites are both elongated medially into processes connecting one with the other in the midline. The cavity of the somite does not continue into the process, the walls here being closely apposed. By further development these somites become greatly enlarged, and are then connected by a cross-canal ('Quer-canal') which, at first narrow, soon becomes extraordinarily wide. The end of the notochord lies in close contact with the posterior wall of the canal. Later the canal disappears and out of the walls of the somite are developed those eye muscles which are innervated by the nervus oculomotorius. ${ }^{1}$

Lying above the first gill cleft and just below the ganglion of the $\mathrm{N}$. trigeminus, or exactly in the position where the second head somite of selachians is situated, Hoffmann found a cell-mass conspicuous on account of the peculiar arrangement of its elements. The cells on the periphery are plainly arranged as an epithelium, lie in a single layer. and enclose a rather indistinct cavity. "so, that quite evidently we have to look upon this cellmass. dis the longlegue of flie: second head somite."

A short distance posterior is the second head somite, but somewtiaf turther mental stage, and on éd side, two smaller separate and dis-

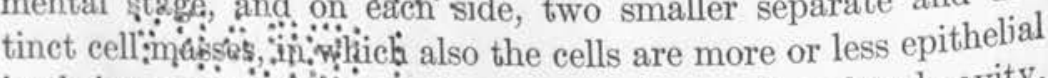
in their arrangement, and show traces of a small enclosed cavity.

\footnotetext{
${ }^{1}$ The muscles supplied by the oculomotor, trochlear, and abducent nerves respectively, will be frequently referred to as the 'oculomotor,' 'trochlear' and 'abducent muscles.'
} 
Hoffmann was at a loss as to how to interpret these two masses, but he stated that it was conceivable that the anterior one corresponded to the third head somite of selachians, the posterior mass to the fourth. As opposed to this he found that the latter did not occupy a position above the second gill pouch and below the auditory vesicle, as does the fourth head somite in selachians, but that it lies above the first gill eleft. Furthermore, in selachians the M. rectus lateralis is developed from the third head somite and is innervated by the N. abducens. In lizards another muscle is also innervated by this nerve, namely the M. retractor oculi. This muscle is not found in selachians. It is probable therefore, according to Hoffmann, that both cell-masses belong to the third head somite and that the anterior mass gives rise to the M. rectus lateralis and the posterior mass produces the M. retractor oculi. This he was unable to verify for lack of material.

The head somites of Anguis fragilis were investigated by Oppel (90). The youngest embryo studied by him was one of 11 segments. At this stage, at the place where Hoffmann found the first head somites of Lacerta, Oppel describes his observations in effect as follows: From the point where the anterior, blind end of the foregut abuts against the floor of the forebrain the mesoderm extends from the midline laterally into the head, on both sides. In front of this point there is no mesoderm. A part of the laterally extending mesoderm is noticeable as being sharply differentiated from the rest. This part grows out laterally from the midline, gradually broadening, and extends anteriorly toward the eye. It has the form of two wings attached at a common point. These mesodermic wings lie behind the optic vesicles, only slightly separated from them, and, curving around them laterally and ventrally, they extend still further forward. The connecting-bridge ('Verbindungs-brücke') of these two wing-like structures, which at the same time forms the point at which the chorda and gut-wall meet, has a posterior protruding thickening or process, in which the end of the chorda disappears. Oppel calls this structure uniting the organs mentioned the prechordal plate ('Praechordalplatte'). The foregut touches 
the prechordal plate below. The mesodermal wings differfrom the surrounding head mesoderm in that their cells are more densely packed. In some sections the cells in the lateral region of the wings are otherwise arranged. There appears here a small cavity, around which the cells are radially placed. Such a structure, according to Oppel, is a characteristic somite.

The cell-stalk which extends from the somite to the midline, Oppel calls the 'Stiel,' and its length, according to him, permits the somite to lie at some distance laterally behind the optic vesicle. The somite portion differs from the corresponding somite found by Hoffmann in Lacerta, in that it is sharply marked off from the 'Stiel' or connecting-stalk.

A short distance anterior to the auditory vesicle, at the side of the hindbrain, Oppel found the homologue of the third head somite of selachians as a mass of cells arranged radially about a small cavity. On the cranial border of this somite, seemingly growing out from it, he observed a smaller rather indefinite cell-mass, which he interprets as corresponding to the anterior of the two somitic structures found at this place in Lacerta by Hoffmann. The structures here were not separate and distinct from each other as in Lacerta, and Oppel was unable to add to the suggestion as to their significance.

Regarding a second head somite in Anguis, Oppel is less certain. In an embryo of eleven segments, however, a short distance caudad of the first head somite and somewhat nearer the midline, he found a small structure which answers the requirements of a typical somite. Oppel's figure shows it in section as having a well defined epithelial wall, one cell deep, enclosing a small but distinct lumen. It has no connection with any other structure, and a similar body occurs also on the other side. In an embryo of thirteen segments he found only a small heap of cells at this place, and in older specimens no further trace of it was found. He could establish no connection between this somite-like body and the later appearing M. obliquus superior.

The Lacertilia have been investigated also by Corning (' 00 ). His observations were made upon embryos of Lacerta muralis and $\mathrm{L}$. viridis, two forms representing essentially like conditions. 
In an embryo of the latter species of 9 segments, two wing-like cell-masses, similar to those of Anguis fragilis, partly enclose the ventral wall of the brain tube; but no structure having somite characteristics is present. The 'Stiel' or connecting-stalk of the somite, in the midline, is connected with the entoderm of the foregut, but Corning makes no mention of a prechordal plate. Later a cavity appears in the lateral part of the winglike cell-mass, which gradually expands into a large sac with walls of cubical ${ }^{\bullet}$ or even flat cells. The cavity has continued through the cellular 'Stiel' so that a very wide canal now connects the right and left somites.

Corning evidently found no structure corresponding to the second head somite of Oppel and Hoffmann, and treats of the development of the M. obliquus superior in connection with the gill-arch musculature, as it arises, according to him, from the dorsal portion of the trigeminal muscle anlage which grows out anteriorly above the eyeball.

For the third head somite this author recognized a structure which he states agrees in every respect with the third head somite of Anguis, and later gives rise to the muscles innervated by the abducent nerve. This somite, he says, is difficult to locate in younger stages, but later is easily found as a cell-mass lying close to the lateral side of the internal carotid artery and somewhat medial to the trigeminal ganglion.

For the Chelonia, the only work on the head somites known to the writer is Filatoff's article ('07) on Emys lutaria. According to this author, the first head somite of Emys is developed from a mass of cells which grows out laterally from the thickened dorsal wall of the anterior end of the foregut. This thickened part of the gut-wall forms at that stage the common origin of both notochord and first head somite. The middle portion of this thickening then differentiates into the chorda, the lateral portions grow outward and give rise to the first head somites. In an embryo of 18 segments the laterally lying first head somites are still connected in the midline by the cell-mass which pushes out from the intestinal wall, which Filatoff now ealls the 'Zwischenplatte,' and which corresponds to the 'Praechordalplatte' of 
Oppel. The end of the chorda approaches this closely, but is separated from it by an insignificant cell-mass which later becomes more sharply differentiated from both the 'Zwischenplatte' and the chorda, but eventually degenerates into mesenchyma. When fully developed the first head somites in Emys are large, thin-walled 'sacs' connected with each other by a narrow canal resulting from the 'Zwischenplatte.'

The second and third head somites were found differentiated in an embryo in which spiracular and first gill clefts had appeared. The second somite lies just below the developing $\mathrm{N}$. trigeminus; it has a lumen and its upper or dorsal wall, especially, is formed by a distinct layer of close-set cells. The third head somite is represented by a heap of cells lying between the second somite and the auditory vesicle, and above the spiracular cleft. In this stage it possesses neither lumen nor the characteristic radiation of cells. Later, however, a rather indistinct radiation appears, and this is the only character, according to Filatoff, which gives this structure claim to being a true somite. A cavity is at no time developed. A compound nature of the somite such as described for the Lacertilia, was not observed in Emys.

\section{THE EYE MUSCLES}

Investigations of the development of the eye muscles in Reptilia have been fragmentary. The works of Corning ('00) and Filatoff ('07) contain the most complete accounts.

According to Corning the oculomotor muscles arise at definite places on the wall of the first head somite. These are chiefly the dorsal and ventral regions, while the lateral region, and the antero-medial wall which is directed towards the optic cup, take no part in the formation of the eye muscles. From the first mentioned parts muscle-forming cells grow out forming muscle 'buds,' and at the same time out-pocketings or folds of the wall occur, but to no great extent. The muscle buds or anlages thus formed grow out dorsally and ventrally, and then take an anterior and lateral direction towards the eye-ball. The ventral outgrowth takes the lead; it is bifurcated at its anterior end, 
and Corning compares these two divisions with Hoffmann's findings for Acanthias, and would call them respectively the $\mathrm{Mm}$. obliquus inferior and rectus inferior. Both are connected with each other for some distance from their point of origin on the somite wall.

The dorsal anlage has not, at this stage, advanced very far and Corning states in regard to it that he was able to establish only that it divides into parts to which the upper branch of the $\mathrm{N}$. oculomotorius is given off, and that these parts give rise to the M. rectus superior and probably to part of the M. rectus medialis. The development of these muscles was followed no further by Corning.

As before mentioned, the M. obliquus superior, according to this author, arises from the dorsal part of the trigeminal or maxillo-mandibular muscle anlage. On plate 6 , figure 33 , he pictures the M. obliquus superior as an uninterrupted dorsal extension of the trigeminal muscle-mass, ending a short distance above the ophthalmic division of the trigeminal nerve. No structure answering to the second head somite of other authors is thus recognized.

The abducent muscles are derived from the earlier mentioned third head somite. Corning does not associate the two muscles of this group with any two divisions of the third head somite, and does not give figures of the last named structure, because, he states, it agrees in every respect with the figure presented by Oppel for Anguis fragilis. From the conditions found in a late embryonic stage of $\mathrm{L}$. vivipara, however, he remarks that, for the musculature innervated by the abducent nerve, one has to distinguish between two origins: a posterior one, from which proceeds the greater part of the M. retractor oculi; and an anterior one, from which the M. rectus lateralis arises. This is because he finds that part of the abducent muscle-mass becomes attached posteriorly to the trabeculae, and part, passing medially between the hypophysis and the trabeculae, becomes attached to the bony plate separating the hypophysis from the oral cavity.

Filatoff's observations on the oculomotor muscles agree with Corning's, but are likewise incomplete. On plate 10, figure 28, 
he shows a dorsal and a ventral thickening of the wall of the first head somite. From conditions shown by a much older embryo, figure 32 , he concludes that the dorsal gives rise to the M. rectus superior and that the ventral one is the common anlage of the $\mathrm{Mm}$. obliquus inferior, rectus inferior, and rectus medialis. The M. obliquus superior he derives from the dorsal part of the second head somite.

The abducent musculature is treated by him as one mass from the time of its appearance as a single heap of cells representing the third head somite, up to the advanced stage shown in figure 32, when, he states, a 'Zweiteilung' has taken place, with a corresponding forking of the abducent nerve.

\section{DESCRIPTIVE PART: MATERIAL AND METHODS}

The following investigation of the head somites and eye muscles in Chelydra grew out of a study of the mesodermic somites of the trunk region undertaken at the suggestion of Dr. B. M. Allen, while doing graduate work at the University of Wisconsin, in the summer of 1910, In continuing this study after returning to Minnesota I became interested in the somites of the head and began a more thorough study of them with the following paper as a result.

A considerable part of the work on this problem including the making of the wax models was done during the past summer in the Laboratory of Comparative Anatomy of the Harvard Medical School. The models were made under the guidance of Dr. Frederic T. Lewis, to whom I am indebted for many favors, helpful suggestions and never failing interest. It is also a great pleasure here to acknowledge the kind interest and encouragement of Dr. Minot, who generously placed at my disposal the entire Reptilian series of the Harvard Embryological Collection, which was found invaluable in checking up and verifying a number of uncertain points in my own series, and for making a number of instructive comparisons. To Drs. Minot and Lewis jointly I am indebted for obtaining the services of $\mathrm{Mr}$. William $\mathrm{T}$. Oliver, of Lynn, Massachusetts, by whom all the drawing of the wax 
models were made, and also for valuable criticism and suggestion in the final preparation of the manuscript.

The material used in this study was obtained by the aid of Prof. H. F. Nachtrieb, from the Embryological Supply Station of Mr. Albert Allen, Madison, Wisconsin. All the material had been faultlessly fixed and preserved. The following fixing agents were represented: Tellyesniczky's bichromate-acetic; sublimateacetic; and Zenker's fluid. The embryos had all been preserved in 80 per cent alcohol.

The specimens prepared for study were stained in toto in Meyer's hemalum for periods varying from twenty-four to thirtysix hours. With the exception of two early series which were not counterstained all the remaining were stained on the slide in eosin. Sagittal sections proved by far the most satisfactory for the study undertaken. But these were in a number of cases supplemented by cross sections of corresponding stages. A number of temporary wax reconstructions were made from time to time, of various structures, to aid in determining their form and relation to other parts.

THE HEAD SOMTTES

The youngest Chrelydra embryo studied in the preparation of this paper was a $2-\mathrm{mm}$. specimen with five segments. In the prootic region of the head the dorsal mesoderm has a compact uniform appearance on each side, becoming less dense towards its anterior limits. A careful scrutiny of the district, however, failed to reveal any differentiation of the mesoderm which might indicate a possible somite area. The next older specimen was a $3.5-\mathrm{mm}$. embryo with ten segments, in which, as the following description will show, the mesoderm of the head presents differentiations, the earliest phases of which undoubtedly may be observed in stages lying between the two here mentioned.

3.5-mm. embryo (10 segments); transverse series: figures 1 to 3

In this embryo the neural tube is still open at the anterior end. Due to the flexure of the tube the plane of section is hori- 
zontal to the region in front of the hindbrain. In carefully examining the anterior portion of this series, beginning with the first sections which are dorsal, and proceeding ventrally, there appears a section at a level slightly above the floor of the mid-brain and passing through both optic evaginations, in which a group of closely packed cells is seen lying in the mesoderm at the side of the neural tube, opposite the constriction between the diencephalon and the mesencephalon. Following this cell-group four sections further ventrally it appears as a well-defined, though rather small, structure in which the cells are arranged radially about a central point; their nuclei are more deeply stained than those in the surrounding mesoderm and lie toward the periphery. In some parts of the structure there seem to be two or three irregular layers of cells, in other parts but one. In the next section (fig. 1) there appears what seems to be a narrow slit-like cavity which can be traced through only two sections. This feature can be made out only with high power (about 300 diameters), but the entire body is readily observed with low power ( 65 to 80 diameters). Four sections further ventrally the limit of the structure is reached. It thus extends through a total of six 8-micron sections. Frequent mitotic figures occur throughout.

Separated from this structure by not more than two sections, a second group of cells appears, smaller than the first, but showing in two consecutive sections a similar radial arrangement of the nuclei about a central clearer protoplasmic area, with doubtful traces of a lumen. Beyond this group, which extends through four sections, no further differentiations in the mesoderm can be seen in this region.

Through the hind-brain region, the plane of section falls at right angles to the neural tube. The notochord follows the flexure of the tube and is sharply bent so that its anterior end is seen in horizontal section, lying slightly separated from the ventral brain wall. On each side, near the ventro-lateral wall of the hind-brain and at the level of the chordal flexure, a sharply differentiated body appears in the dorsal mesoderm, which resembles a typical somite (fig. 2). Each of the bodies consists of a 
layer of tall cells, apparently two or three deep, arranged about a well formed cavity. The one on the left side is the larger and better developed of the two, but in actual size is smaller than the dorsal member of the more anterior group. The cavity can be traced through seven sections. The entire body with its lumen is slightly compressed laterally, so that its dorso-ventral diameter is greater than the latero-medial. Its long axis is parallel to the long axis of the embryo, agreeing in this respect with the two components of the group first described. A short distance caudad the auditory plate appears, and no further mesodermic structures are seen till the first opisthotic somite is encountered just posterior to the auditory plate.

Turning our attention now to the most anterior region of the head mesoderm, in the same section represented by figure 2 there may be observed an elongated area on each side of the forebrain vesicle, which is marked off from the adjacent mesoderm only by the closely packed condition of its cells (S 1). Each mass extends from near the median line antero-laterally, fcllowing the border of the fore-brain wall. Followed out, these cellheaps expand somewhat anteriorly and laterally, and a section passing through the antero-dorsal wall of the foregut shows a rather short bridge of cells connecting the right mass with the left, producing a dumb-bell shape. At its middle this connecting bridge is seen to form a part of a mass of cells pushing out from the anterior dorsal wall of the foregut (fig. 3). The anterior end of the notochord enters this outgrowing cell-mass from the posterior side and becomes indistinguishably fused with it. The two laterally growing cell-masses, therefore, arise from a median mass which pushes out from the entoderm of the anterior dorsal wall of the foregut.

From the position and relations of the three sets of structures here described, it is clear that they represent the three prootic head somites described by Filatoff for Emys lutaria, and by other authors for a number of representatives of the Lacertilia. From anterior to posterior they are designated the first, second, and third head cavities or somites, or the premandibular, mandibular, and hyoid somites (S 1, S 2, S 3). 
The two lateral cell-masses, representing the first head somites, accord perfectly with Filatoff's account of the early stages of these somites in Emys. No cavities are as yet to be found on either side. The cells have no definite arrangement nor are they individually distinguishable from ordinary mesenchymal elements. Mitotic figures are numerous and it is evident that the mass is in active proliferation, growth in size taking place both by addition from the wall of the foregut and by cell division within the mass itself. A carefully made wax reconstruction of the region involved shows the first head somites as two quite similar, somewhat irregular masses, which press out on each side from the narrow space enclosed between the floor of the forebrain vesicle and the wall of the foregut. In each, the large anterior portion narrows somewhat postero-medially towards its origin in the outpushing entodermal cells of the digestive tube. The upper sides of the two somites form a trough-like hollow, closely surrounding the floor and sides of the prosencephalon. Anteriorly they reach to the tip of the neural tube.

The second and third bead somites in Chelydra lie in a portion of the head mesoderm which is a direct continuation forward of the dorsal mesoderm of the trunk and occipital regions. They somite in that their cells Filatoff points their cells have a typical radial arrangement. quate in that it do however, that Dohrn's definition is inadesomites in the ascending allow for variations in the form of head conditions of their plete obliteration of their cavities and resulting perhaps in comtypical, radial cell order. In Chelydra the second shows the very marked radial Chelydra the second head somite cannot, at this stage at least, bell order, but a clear cut lumen that if a sufficient number of be claimed for it. It is probable developmental stage were examined a f approximately the same exist. In the present investigation a lumen would be found to investigation but one other embryo of

\footnotetext{
'Dohrn, a. Studien zur Urgeschichte des Wirbelthierkörpers. Mittheil. aus
der Zool. Station zu Neopel. Bd. 15.
} 
precisely the same number of segments was available, and in exactly the same position a cell-group surrounding a small but distinet lumen was found in one section, but as the sections adjacent had been partly lost or mutilated, nothing further could be learned. In the embryo described, the opposite side (the left) presented less advanced development. No such radial cell structure was present, but a rather inconspicuous mass of cells indicated what undoubtedly would have resulted in a corresponding structure. In regard to the second smaller component of the second head somite, it is doubtful whether it is constant, or has any other significance than that it indicates a tendency of the second head somite to split up,-a step towards the diffused condition of this area in birds, as found by Rex. The present phase of the somite is evidently maintained for only a brief period, for in the embryo with ten segments, it was still undeveloped on the left side, and, as will subsequently appear, relatively large cavities soon take its place, which little suggest an earlier somite form.

The third head somite of Chelydra differs markedly from the corresponding somite in Emys in that it possesses a very clear radial cell structure and a well defined conspicuous cavity. In Chelydra, therefore, this somite approaches closely the typical somite form.

4-mm. embryo (13 segments); sagittal series: figures 4 to 7

Distinct advance is apparent in this stage. Cavities have appeared in the first head somite. In the preceding stage, it will be recalled, the anterior end of the notochord disappeared in the thickened dorsal wall of the foregut, from which the cellmasses constituting the first head somites grew out laterally. At the point of cell outgrowth there now lies a median oval thickwalled epithelial body, with narrow central cavity, closely wedged in between the infundibular region and the dorsal anterior wall of the foregut. Its anterior end abuts ventrally against the ectoderm where the invagination of the hypophysis later appears (fig. 4). This structure is the 'Praechordalplatte' of Oppel or 
'Zwischenplatte' of Filatoff. The notochord enters its posterior wall, making it appear as though its tip were expanded into the thick-walled prechordal plate.

Owing to the increasing size of the fore-brain the first head somites have been pushed back so as to lie nearly at right angles to the notochord. They are still much flattened in the anteroposterior direction. On the right of the embryo the somite is attached to the anterior end of the prechordal plate by a narrow stalk of cells proceeding from its ventro-medial surface; the somite of the opposite side presents a similar short stalk, but is completely separated from the prechordal plate. In sagittal sections passing through the middle of these somites, each appears as a short crescent, convex posteriorly. There is a relatively large cavity in the dorsal horn, which, followed laterally, branches into two narrower cavities. From the latero-posterior side of the somite a rather slender cellular process extends a short distance caudo-ventrad into a denser portion of the mesoderm of the mandibular arch, which is directly continuous ventrad with the pericardial mesoderm. A cavity is present in the distal end of this process. At this point it will be seen later that the first head somite becomes closely associated with a number of smaller cavities and cell-clusters appearing in the condensed mesoderm area of the mandibular arch, which give rise to the maxillomandibular musculature.

The second head somite has undergone a marked change. In exactly the same position occupied by the two somite-like structures of the foregoing stage there here appears a very large, somewhat globular vesicle with a smaller, roughly oval, vesicular appendage on its antero-dorsal wall (fig. 5). The cavities of the two are not continuous. Their respective positions do not point to a formation from two such components as found in the earlier embryos. Individually the cells of the wall do not differ from the surrounding mesenchymal cells, yet, when the structure is viewed as a whole, their close order around the sharply limited lumen, and the numerous deeper-staining nuclei readily distinguish this cavity or somite from other mesenchymal spaces. In many places the wall is distinctly drawn away from the sur- 
rounding mesenchyma, and delicate cytoplasmic processes bridge the intervening spaces.

The third head somite also presents marked differences. Instead of the single eavity of the $3.5-\mathrm{mm}$. stage there lies in its place a compound structure having the appearance of a somite which is about to be divided by a circular constriction into two parts (fig. 6). Each part has a relatively large and distinct lumen, separated entirely from that of the other by a rather thin partition of cells pushed inward from the wall of the somite. The $\mathrm{N}$. trigeminus passes obliquely outward in close proximity to the dorsal wall of the anterior division.

A eloser examination of the two parts of this somite shows a number of differences between them. The two are of unequal size. In the posterior division the wall is thicker, and its cells are arranged as a well-defined epithelium about the lumen. This part of the somite also lies further mediad. On the anterior side its wall becomes noticeably thinner, beyond the constriction, as it there passes directly into the wall of the anterior division. The cavity of the latter is somewhat larger. This latter portion of the somite is in the first stages of expansion into the so-called 'cavity' phase. Its wall has come into contact and fused with the median wall of the second head somite, and a narrow canal leads from one into the other. This close association of the second and third head somites is the direct result of the expansion of the two structures, especially of the former.

In the present stage it can be seen that a portion of the mesoderm, extending from just below the outer edge of the second head somite down to where it passes over into the pericardium, has become more densely packed; and immediately ventrad of this somite and adjacent to the ventro-lateral diverticulum of the first head cavity, small clusters of mesodermal cells appear, varying in size, in part solid, and in part enclosing cavities. This entire differentiated area forms the anlage of the musculature of the mandibular arch.

The opposite side of the embryo shows conditions essentially similar, but the second head eavity is more irregular and is flattened somewhat in the antero-posterior direction. It has two 
detached vesicles on its postero-dorsal wall. There is no connection on this side between the cavities of the second and third head somites, though their walls are closely approximated. Figure 7 is taken from a second embryo of the same age, and it shows the transition stage between the third head somite of the 4-mm. embryo and that of a $5-\mathrm{mm}$. specimen presently to be described. It shows clearly the transformation of a typical somite into a large thin-walled vesicle such as, in all head somites, forms the most striking phase.

\section{5-mm. embryo; transverse series: figures 8 and 9}

A number of sections of this series in the region of the second and third head somites were broken in mounting, and thus rendered unreliable for observation on those structures; but the region of the first head somites is well preserved, and here considerable advances over the preceding stage have taken place. The dorsal parts of these two somites have expanded into large thin-walled cavities, triangular in section, with their bases in close proximity to the optic vesicles and their apices approaching each other near the midline. Further ventrally the large cavity ends, and as seen in sections passing through the prechordal plate, the structure becomes more irregular and consists of a dense cell-mass in which a number of larger and smaller cavities are forming and coalescing, whereby the main cavity becomes gradually extended ventrally and medially into the connectingstalk (fig. 8). On one side only, the left, is the somite connected with the prechordal plate (fig. 9). The plate itself shows decided change. It is reduced in actual size, its cavity is larger, and the walls are thinner and looser. On one side the cells of its wall continue into a short, more or less tubular stalk, the wall of which then expands laterally into the head somite. There is no connection as yet between the lumen of the prechordal plate and the cavities in the stalk. On the opposite side the connectingstalk ends freely a short distance laterad of the prechordal plate.

The short flexed portion of the notochord next to the prechordal plate is peculiar in that it is more slender than the 
following posterior portion, and is somewhat wavy in its course, giving the impression that it is preparing to disintegrate. Such, however, is not the case at this time. It is still attached to the prechordal plate. In figure 8 the group of cells near the prechordal plate is a part of this section of the chorda.

5-mm. embryo (20 segments); sagittal series; reconstruction: figure 19

On the right side of this embryo the first head somite is a large smooth-walled vesicle, flattened somewhat in an antero-posterior direction, and tapering rapidly medially where its wall passes into a short thin cell-strand (connecting-stalk), ending close to the ventro-medial side of the prechordal plate. Within the median half of the vesicle a slender cell-band extends from the anterior to the posterior wall, being the only remains of the earlier solid mass of the interior. In the ventro-lateral wall of the somite the hollow process of the younger stage is represented by a prominent diverticulum $(d v$.$) , which tapers down into a$ short loose strand and becomes lost in the more extensive and conspicuous cell-clusters in the mesenchyma which give rise to the maxillo-mandibular musculature.

The left somite is essentially like the right but somewhat more expanded. It is also connected, through its stalk, with the prechordal plate. A solid portion of the stalk next to the latter structure shuts off communication between their cavities.

Measurements of the prechordal plate at this time show that it is very considerably reduced, as compared with the $4-\mathrm{mm}$. stage, in all its dimensions. This reduction is the result of the drawing in of its cells into the somite wall by way of the median stalk.

The second head somite of this stage lies somewhat laterad, between the ophthalmic and maxillo-mandibular divisions of the $\mathrm{N}$. trigeminus. Its vesicles here reach their maximum size. As seen in the model the right somite consists of two main lobes or vesicles: a larger dorsal lobe, and a smaller ventral one. The cavities of the two connect by a narrow canal. The dorsal lobe 
is itself divided into two nearly equal lobes by an indentation on its lateral side. The ventral vesicle is intimately associated with the muscle anlage of the mandibular arch, in the same way as the diverticulum of the first head somite.

The muscle anlage of the mandibular arch is here differentiated into an irregular, rather extensive dorsal part, and an elongate narrow ventral portion leading down through the arch, in a ventro-medial direction, as far as the pericardium. This ventral portion is now a very well differentiated district in the mesenchyma, and its cells are deeply stained and densely packed; but here and there throughout its extent a number of open spaces occur. The dorsal portion is looser in structure and is less sharply marked off from the surrounding mesenchyma. It seems a common characteristic of the cells of these districts to first form small solid spherules, and then develop cavities, a process quite similar, on a minute scale, to that occurring in a somite.

On the left side of the embryo the second head somite forms a single large cavity, the longer axis of which is caudo-ventral. No connection with the cavity of the third head somite can be made out, but its dorso-medial wall is in contact with the anterior vesicular portion of the latter. Its relations to the mandibular arch musculature are the same.

The third head somite, like the second, in this stage reaches the maximum development of its eavity-phase, but it is a smaller structure. As a whole this somite is elongated, reaching from a short distance anterior to the facio-acustic ganglion to the dorso-medial wall of the second head somite. The anterior division is a thin-walled sac which is fused on its ventro-lateral side with the dorso-medial wall of the second somite. A broad canal connects the cavities of the two. In the posterior division of the somite the cells have for the most part lost their former more definite epithelial order, retaining it only on a part of the median wall. They appear greatly increased in number, are less sharply limited at the periphery, and loosely surround a relatively small cavity which opens abruptly into the larger cavity of the anterior division. In form this part of the somite is more elongate than formerly. The anterior division of the 
somite lies snugly in the angle formed by the ophthalmic and maxillo-mandibular divisions of the $\mathrm{N}$. trigeminus. The trunk of the maxillo-mandibular division lies close against the outer wall of the somite, between its anterior and posterior divisions.

On the left side conditions are similar. The anterior division of the somite seems somewhat more expanded, and on its ventrolateral side there is a small detached vesicle lying close against its wall. In the posterior division an irregular cavity remains within the loose cell-mass. Between the two portions of the somite is a loose cellular partition, but no open connection between the enclosed cavities is found.

\section{6-mm. embryo; sagittal series: figures 10 to 12}

The first head somite of this embryo differs from that in the preceding specimen chiefly in its more expanded condition. In its lateral portion a horizontal septum gives it a two-chambered appearance. On each side the prominent diverticulum of the preceding stage is represented, reaching down to meet an extension of the maxillo-mandibular muscle-mass. This mass or anlage here presents a very sharply defined form throughout most of its extent, being least definite in its dorsal extension towards the first and second head somites. Its long ventral portion, extending down through the mandibular arch, is a thick-walled tubular mass very suggestive of the visceral portion of the mandibular somite in elasmobranch embryos. Dorsally it divides into two short diverging processes, one directed anteriorly (fig. $10, p r$.) to meet the diverticulum from the first head somite, the other extending towards the second head somite, becoming irregular and indefinite in its upper portion, where it spreads into a diffused area of small cavities and solid cell-elusters.

The prechordal plate is further reduced in size, having been gradually drawn into the median connecting-stalk of the left somite, with which alone it is connected. On account of the increased expansion of the head cavity, the stalk has become shorter proportionately, and now forms a short, rapidly tapering tube on the inner ventral wall of the somite. The somite cavity extends into its base, but the apical portion is solid and fused 
with the prechordal plate. On the opposite side the somite has, as before noted, no connection with the prechordal plate.

The rate at which the prechordal plate becomes incorporated into the stalk of the first head somite seems to vary. In another embryo of apparently precisely the same age, the plate is of considerably larger size, lying as a short transverse tube, with compact epithelial walls, against the end of the chorda. On the right side it tapers into a slender cell-cord which then enlarges into the somite stalk. On the left a broader connection exists. The wall of the prechordal plate continues directly into the tubular stalk of that side, and its lumen is confluent with the cavity of the latter. Thus it is evident that the prechordal plate becomes embodied in the stalks of the first head somites and therefore really forms a part of their walls. It is not equally divided between the two, but may be taken up in greater part by either the right or the left, as the case may be.

The second head somites in two series of the stage here concerned show essentially like conditions, but minor variations appear in each. Figure 11 is chosen from the second of the two series, and here the somite is represented by a larger bilobed vesicle which has a smaller simple one lying against its anterior wall. The bilobed form of the larger vesicle is caused by the deep indentation of its lateral wall. This somite is the simplest of the mandibular somites in the two embryos, since it has the smallest number of lobes and independent cavities. In the others a greater number of cavities occur but they are of smaller size. In all cases, however, the cavities of the second head somite are sufficiently closely grouped so that they may readily be distinguished as a whole from the similar though generally smaller cavities of the mandibular arch.

The third head somite is represented by a large mass of cells occupying most of the space between the trigeminal and facioacustic ganglia (fig. 12). The roof of the hyomandibular cleft approaches it closely from below. A large, densely packed mass forms its posterior division, and from the anterior side of this a narrow depressed cell-heap extends forward, closely hugging the ventro-medial side of the maxillo-mandibular division of the 
trigeminal nerve, which it barely crosses. This represents the anterior vesicular portion of the somite. Its cells are spindleshaped, and all lie in a general longitudinal direction. In the posterior portion of the somite the cells are for the most part promiscuously heaped, but they assume a distinct spindle form anteriorly on the outer side, where they pass over into the anterior division.

\section{7-mm. embryo; sagittal series}

In this embryo the beginning of the epiphysis is present as a distinct epithelial bud. In general form the first head somite is the same as in the preceding stage, but it is somewhat larger. On one side the narrow distal end of its ventro-lateral diverticulum has fused with the neighboring end of the tubular process from the muscle anlage of the mandibular arch, and only a few loose cells on the inner wall of the latter, separate their cavities. This is the most intimate association between the first head cavity and the cavities of the mandibular arch found in the present study. The other side of the embryo, however, shows relations essentially as in the preceding stage.

The prechordal plate is almost entirely absorbed into the median stalk, in this case the left. It is simply a slender solid cell-cord which rapidly broadens into the stalk. The end of the notochord has severed its connection with the prechordal plate, and is more sharply bent ventrally and backward, so that it touches the plate with its dorsal side.

A second embryo of the same measurements, and of equally advanced development, shows a condition of the prechordal plate which is a further instance of the irregularity of the developmental changes in this structure. In this embryo the plate presents an appearance almost identical with that described for the distinctly younger second series of the 6 -mm. stage, i.e., it is a relatively large tubular structure with epithelial walls, lying transversely at the end of the notochord which is closely attached to its posterior wall. In the older embryo the cells of the wall at this point are partially drawn out, as if unable to separate from the end of the notochord. That a part of the prechordal plate may thus remain attached to the chorda and become ab- 
sorbed in the mesenchyma, seems probable from the facts in the series which follow.

The second head somite of the 7-mm. stage is of such indistinct and indefinite form that it may easily escape notice. It reaches here the most obscure phase of its development. The more or less conspicuous cavities of earlier stages have collapsed and broken down, and with their disappearance the cells of their walls are with difficulty distinguished from the intruding and intermingling mesenchymal elements. There is a tendency, however, for the cells bounding the cavities to form tiny scattered clusters, and these, together with a few stringlets which are unmistakable portions of the cavity walls, make it possible, guided by its position with respect to the trigeminal ganglion, to determine the approximate extent of the somite district.

Processes similar to the above are taking place in the muscle anlage of the mandibular arch immediately adjacent to the second head somite, but the cavities in this area persist somewhat longer. Nevertheless it is difficult at this stage to draw any sharp line between the two districts.

The third head somites in this embryo have essentially the same appearance as in the $6-\mathrm{mm}$. series represented by figure 12.

\section{8-mm. embryo; sagittal series}

The most noticeable change in the first head somite of this stage is that it has still further expanded so that the ventrolateral diverticulum has been practically obliterated in the process, a shallow broad depression alone remaining. The somite is now a thin-walled sac, flattened in the antero-posterior direction, and tapering rapidly medially into a conical hollow stalk. There is no connection between the somites of the two sides. The prechordal plate is no longer found, having been entirely taken up into the stalk and medial walls of the somite. The notochord is still more sharply bent back so that its tip seems to be in actual contact with the oral entoderm a short distance posterior to the hypophysis. A slight but distinct protrusion of the dorsal entodermal wall occurs at this point. The tip of the chorda bears a small group of cells which clearly differ from 
the cells of the notochord itself, and, as before suggested, evidently have been detached from the prechordal plate. The oculomotor nerve has increased in length and now lies close to the posterior wall of the first head cavity.

The second head somite is now reduced to a mass of mesenchymal cells, passing gradually over into the surrounding mesenchyma at the periphery, yet distinguishable as a whole by its denser structure and its noticeably deeper-staining nuclei. A few diminutive cavities may occasionally appear.

The third head somite shows advances over the preceding stage in that it is appreciably larger, more compact in structure and more definite in form. It here consists of a larger cell-heap forming the posterior portion of the somite, from the anterolateral side of which there extends forward a narrow elongate mass which lies opposite the space between the two divisions of the trigeminal nerve and which represents the anterior portion of the somite. The maxillo-mandibular division of this nerve lies against the middle of the lateral side of the cell-mass so that the position and relations of the two earlier vesicular divisions of the third head somite have practically remained unaltered.

\section{Summary}

In the foregoing account it has been observed that during the developmental changes which have taken place thus far in the head somites, the anatomical positions of these structures have been maintained throughout, the changes having been chiefly those of form and size. From the small characteristic structures found in the earliest stages, the second and third head somites, after developing into relatively large vesicular bodies, have been resolved by the breaking down of these, into more or less compact masses of mesenchymal and spindle-shaped cells. These resulting cell-masses are the anlages of certain muscles of the eye. The second produces the M. obliquus superior, and the third the so-called abducent muscles, the $\mathrm{Mm}$. rectus lateralis and retractor oculi.

The first head somite, differing in its early ontogenetic history from the second and third, has arrived at the maximum expan- 
sion of its cavity, and greatly exceeds in size that attained by either of the other two. From the walls of this vesicle the remaining muscles of the eye, the so-called oculomotor group, are destined to arise. Since in the next following stage the first traces of these muscles appear, the further history of the head somites will be followed under the section dealing with the development of the eye muscles. In this process of development the abducent muscle anlage is the first to appear, followed successively by the anlages of the superior oblique muscle and the oculomotor group. For this reason it is thought best to treat the groups in this order.

\section{THE DEVELOPMENT OF THE EYE MUSCLES}

9-mm. embryo; sagittal series; reconstruction: figure 20

In this specimen the epiphysis and paraphysis are both prominent outgrowths. The nasociliary branch of the ophthalmic nerve extends forward over the dorso-median surface of the optic cup. The short mandibular nerve (man. v.) indents the upper portion of the maxillo-mandibular muscle-mass on its lateral surface but the maxillary nerve has not yet appeared. In the second and third branchial arches condensations of the mesenchyma have appeared, forming the muscle anlages (mus. 2,3 ) of these arches, and the facial and the glossopharyngeal nerves extend ventrally along their respective borders.

The abducent muscle-mass lies in the horizontal plane, just mediad of the maxillo-mandibular trunk of the N. trigeminus. Viewed from the dorsal side, as seen in the model, it is a stout mass in which the two divisions before described are well shown. The more rounded posterior portion (retr. oc.) lies nearer the midline, and the anterior part (rect. lat.), represented by an elongate narrower extension from the lateral or outer half of the former, reaches considerably beyond the maxillo-mandibular nerve trunk. In sagittal sections the cephalic end of the anterior division presents a heaped-up disposition of its cells, which differentiates it easily from the rest of this division, in which the spindle-shaped cells have a uniform parallel course. This differ- 
entiation becomes more pronounced in the following stages, and is the beginning of a process by which the M. rectus lateralis, represented by the greater part of the anterior division, becomes more and more distinct from the retractor oculi portion, which is posterior.

The abducent nerve ( $n . a b d$.) could first be found in this stage. It may be seen as a short slender strand parallel with the ventral wall of the brain, and the first impression is that it lies isolated in the mesenchyma, having connection neither with the brain nor with the abducent muscle-mass. Even under careful examination with high power, its distal end could not be traced to the muscle, but its proximal end was seen to be connected with the brain by a number of very delicate filaments or rootlets, three of which can be clearly followed out. In following stages a greater number of such rootlets occur. By the union of these delicate strands the stouter portion of the abducent nerve is formed, which is readily observed; but before their union the rootlets may easily escape notice.

The muscle-mass of the second head somite shows important changes. Its dorsal portion is moving forward as a strong stream of spindle-shaped cells, which is dorsad of the eye-ball and just laterad of the nasociliary nerve. The remaining ventral portion of the somite is in immediate contact with the maxillo-mandibular muscle-mass, but is easily distinguishable from it. Its célls are spindle-formed and directed ventrally. In sagittal sections the entire mass thus presents two divergent cell-streams: the dorsal forward growing part is the M. obliquus superior (obl. sup.); the ventral portion $(x)$ is of doubtful destiny.

The upper or dorsal portion (max.) of the maxillo-mandibular muscle-mass has become more sharply differentiated from the longer ventrally extended portion (man.) and is a dense structure lying at right angles to the latter. It is narrowly separated anteriorly from the ventro-lateral wall of the first head somite.

The oculomotor muscles. The right and left premandibular somites in this stage are united by a narrow transverse canal, formed by the union of the somite stalk of each side with the prechordal plate. As noted also in the 8-mm. specimen, the 
notochord has a group of cells attached to its tip, which in appearance are quite distinct from its own; and a loose patch of similar cells extends from it to the postero-ventral side of the transverse connecting-canal, in the midline, that is, to that part of the canal which corresponds to the prechordal plate. These cells here also are clearly a part of the latter structure, which has become detached along with the chorda.

From a relatively small area on the extreme ventro-lateral wall of the first head cavity, a rather narrow outgrowth of cells extends forward. The basal portion of the outgrowth receives a slight and irregular extension of the somite cavity; its distal part is simply a mass of spindle-formed cells directed towards the ventral side of the eye-ball. The outgrowth is the anlage of the M. obliquus inferior (obl. inf.) (See also figure 13.)

The oculomotor nerve has grown further ventrad, and lies in close contact with the mid-posterior wall of the somite. In this region there appears a thickening in the somite wall, but it is so slight that without the aid of the stages following it would be considered of no significance. It is the anlage of the M. rectus superior, and is destined shortly to become the largest member of the oculomotor group.

The opposite side of the embryo presents practically identical conditions.

10-mm. embryo (a); sagittal series; reconstruction: figures $21 a, 21 b$; sections: figures 14 to 17

The abducent muscle-mass in the 9-mm. embryo already described has the form of a stout rod which is somewhat convex externally. In the $10-\mathrm{mm}$. specimen the anterior portion of the rod, which gives rise to the M. rectus lateralis, has grown out laterally, as seen in figure $21 b$. This lateral portion is closely wedged into the angle formed by the anterior cerebral vein in front, as it bends downward to enter the vena capitis medialis, and the V. capitis medialis ${ }^{3}$ behind, as it ascends and passes

3 The vena capitis medialis is the primary vein of the head, situated medial to the cerebral nerves, close to the wall of the brain. Grosser, O. Die Elemente des Kopfvenensystems der Wirbeltiere. Verh. der Anat. Gesellschaft, Würzburg, 1907 , p. 180. 
backward. The latter vein extends along the outer surface of the larger caudally directed part of the muscle-mass, which gives rise to the $\mathbf{M}$. retractor oculi. There can be little doubt that the relation to the veins is a considerable factor in hindering the forward migration of the abducent muscles at this stage, and in directing them outward. In the model the $\mathrm{Mm}$. rectus lateralis and retractor oculi are not sharply differentiated from each other, but in sagittal sections they are well defined, owing to the difference in the direction of their cells, and to the fact that the M. rectus lateralis is more compact. The cells of the M. retractor oculi have migrated forward, extending somewhat dorsally and laterally over the inner end of the M. rectus lateralis, so that in sections the latter muscle, at this end, appears as a heap of cells crowded to a greater or less degree ventrad of the anterior end of the M. retractor oculi (fig. 17). A crossing of the two muscles is thereby begun.

The abducent nerve can now be traced to the M. retractor oculi which it penetrates on the median side of its tapering caudal end.

The $M$. obliquus superior has greatly increased in length and extends forward in a gentle curve above the dorso-medial surface of the eyeball. Its structure is most compact at about its middle, where it is slightly thicker; it tapers anteriorly and also posteriorly to where it is continuous with the remaining ventral portion of the original somite. This latter part retains its previous relation to the $\mathrm{N}$. trigeminus and to the dorsal mass of the maxillo-mandibular musculature, but is somewhat reduced in extent through its contributions to the M. obliquus superior. Its cell-structure is more open than that of any of the differentiating muscle-masses. The dorso-ventral direction of its distinctly spindle-formed cells suggests that they are moving ventrally to fuse with the maxillary and mandibular musculature; but the latter gives no evidence of having received additions from this source, with the exception, possibly, of the part directly adjacent. In figure 16 it would appear as though a dorsal group of cells of the maxillary portion of the muscle-mass were formed entirely by cells from the mass $x$, but in reality it is but a part 
of the now very compact and lobulated dorsal end of the maxillomandibular musculature.

The continued connection of the mass $x$ with the M. obliquus superior and the great length of the latter, are peculiar features of this stage.

The oculomotor group. The premandibular somites are now well drawn away from the median line, and on the left side only is there a remnant of a former stalk or cross-canal. The two cavities are quite similar in form and show little difference in size, but the right is a trifle more advanced in the development of the muscles. The dorso-lateral wall of each is disintegrating (fig. $21 \mathrm{~b}$, Mes.). Its cells are passing out into the surrounding mesenchyma and pushing into the somite cavity. The inferior oblique muscle (obl. inf.) is large and forms a solid club-shaped mass reaching ventrad well beyond any other portion of the somite. The anlage of the rectus superior (rect. sup.) is well established as an extensive solid thickening involving a large portion of the upper half of the posterior wall of the somite. It is roughly quadrangular, being narrow medially and widening laterally, where it is closely covered by the ciliary ganglion. This thickening of the wall takes place by an outward proliferation of cells and no perceptible protrusion into the interior of the somite occurs. The position and relations of the anlages of the right and left sides of the embryo are identical.

In the lateral half of the somite its posterior ventral wall sends out a deep sac-like evagination, the outer side of which is closely apposed to the median side of the upper half of the M. obliquus inferior. The posterior and ventral sides of this sac are thickened. The ophthalmic artery crosses the middle of its posterior wall, and turns cephalad, passing in between the evagination and the M. obliquus inferior, and emerging on the anterior side. The large evaginated portion in question is the common anlage of the $\mathrm{Mm}$. inferior rectus and rectus medialis (inf. + med. recti).

The ciliary ganglion (cil. g.) at this stage appears as an accumulation of cells which form a thickening of the N. oculomotorius toward its distal end. On the right side the nerve extends a short 
distance beyond the ventral border of the ganglion. In older stages the nerve lies near the medial surface of the ganglionic mass from which it gradually becomes separated until it lies free along the medial side of the ganglion; the two are then connected by the so-called short root of the ganglion.

The notochord at this stage is slender, and slightly wavy in its anterior portion, and has a small cluster of cells attached to its tip, as in previously described instances.

\section{0-mm. embryo (b)}

Although the measurements for this embryo were the same as for the preceding specimen ' $a$,' its developmental conditions are somewhat more advanced. The $\mathrm{N}$. trochlearis could here be found for the first time. It extends forward from the brain toward the $\mathrm{N}$. oculomotorius, which it has not yet crossed, and it is still some distance from its muscle. Even after assiduous search, it could not be found in the preceding embryo.

The premandibular somites have suffered extensive changes. On one side the wall has completely broken down and the cavity has disappeared. The only mark of its former existence is an area of sparsely distributed mesenchyma conforming somewhat to the earlier outline of the cavity. On the other side parts of the somite wall are still seen intact in sections cutting the inner end of the M. rectus superior. Laterally the wall becomes more broken down, and the cells grade insensibly into the general mesenchyma. The medial wall of the first head cavities is thus the last to break down, and this is probably due to the fact that this side is least affected by the disturbing influence of the developing eye-muscles.

\section{1-mm. embryo; sagittal series; reconstruction: figure 22}

The abducent muscles have made decided progress. They are now well differentiated and distinct muscles situated close to the posterior surface of the eiliary ganglion, medial and ventral to the ophthalmic division of the N. trigeminus. The cells of the M. retractor oculi have continued their movement forward 
and downward, so that they now form a triangular mass at the anterior extremity of a slender stalk of cells, as seen in figure 22. This stalk of inflowing cells is the belated caudal end of the muscle, and in it lies imbedded the abducent nerve.

The M. rectus lateralis in the former stage occupied a more anterior position than the M. retractor oculi, but this is no longer the case since its forward movement has been proportionately less. It is now an elongate, more or less conical mass, taking the same general ventral direction as the M. retractor oculi, but it is also directed laterad at an angle of about fifteen degrees from that muscle. Its base abuts against the median side of the broad upper portion of the retractor, and its apex points towards the posterior equatorial region of the eye-ball. It is a much smaller mass than the retractor portion.

The $M$. obliquus superior is here an elongate mass, narrow and cylindrical at its posterior end, but broad anteriorly, where it is flattened in the dorso-ventral direction. It lies close to the surface of the eye-ball, parallel to and slightly mediad of the equator, projecting out beyond the surface of the eye anteriorly. Its posterior end is in close association with the distal end of the M. rectus superior. These ends are destined to be extended further forward on the eye-ball before their insertion becomes established. The N. trochlearis can be traced to within a short distance of the posterior end of the M. obliquus superior, but actual connection cannot be demonstrated.

With respect to the ventral portion of the second head somite, embryo ' $\mathrm{b}$ ' of the 10-mm. stage and the 11-mm. specimen show ' practically identical conditions, both in structure and in relation to the developing maxillo-mandibular muscles. In the 11-mm. embryo, however, conditions are somewhat clearer and here small branches from the adjacent veins have penetrated the ventral cell-mass of the second somite. The lateral and medial portions have a more open and decidedly mesenchymal appearance, but towards the middle of the mass the structure becomes more compact, and the spindle-shaped cells with their elongate nuclei resemble muscle-forming tissue. As a whole, the mass appears to be undergoing retrogressive changes. 
Oculomotor group. We have seen that the M. obliquus inferior was the first of this group to appear. In the view of the model shown in the figure, this muscle is largely covered by others and to facilitate description it will be taken up last.

The M. rectus superior has now become large and its end of insertion is in close relation with the end of insertion of the M. obliquus superior. Like the last named muscle it is slender at its distal end and increases in diameter towards its end of origin. It extends in a postero-medial direction and crosses the N. oculomotorius at its entrance into the eiliary ganglion, lying in close contact with the anterior surface of the nerve. In crossing it receives a branch from the $\mathrm{N}$. oculomotorius, which enters its dorsal side. It then makes a sharp turn dorsad and again mediad, so that at this stage it lies approximately at right angles to all the other muscles of the eye. The M. rectus superior, it will be noticed, is now developmentally in advance of the other eyemuscles, baving most nearly reached its definitive position and relations.

The nasociliary branch of the ophthalmic nerve dips under the M. rectus superior just laterad of the point where it crosses the N. oculomotorius, and takes its course anteriorly, following closely the median surface of the eye-ball.

The $\mathrm{Mm}$. rectus inferior and rectus medialis form one elongate mass extending antero-ventrally over the medial surface of the eye, crossing the optic stalk ventral to its junction with the eye-ball. Just below its middle an oblique constriction divides the mass into two club-shaped portions with their enlarged ends anterior: the dorsal is the $\mathbf{M}$. rectus inferior, and the ventral is the M. rectus medialis. The ophthalmic artery lies against the posterior narrower end of the M. rectus inferior on its medial side. Both muscles have received their branches from the N. oculomotorius. This nerve passes ventrally from the medial border of the ciliary ganglion, curves gently forward, and crosses the attenuated district between the two muscle-masses to penetrate the M. rectus medialis on its medial side. Opposite the thickened distal end of the M. rectus inferior it gives off the branch which enters this muscle on its postero-lateral side. 
The M. obliquus inferior at this stage is situated at the outer side of the M. rectus medialis, extending slightly beyond it anteriorly. Its posterior end lies transversely across the slit-like remains of the optic groove. Like the two preceding muscles, it is also stoutly club-shaped, with its broad end anterior. On neither side of the embryo is there as yet any branch from the N. oculomotorius to this muscle, which is the only one of the group that has not received its nerve supply.

\section{Chelydra embryo with carapace of $8.5 \mathrm{~mm}$.}

Figure 23 is a reconstruction of the eyeball with its associated muscles and nerves, of a 9-mm. Chrysemys marginata belonging to the Harvard Embryological Collection (Series 1085). It represents a stage in development of the eye muscles considerably advanced over that of the preceding stage of Chelydra. A reconstruction of these parts of an embryo Chelydra serpentina with a carapace length of $8.5 \mathrm{~mm}$. shows a somewhat more advanced condition, but one directly derived from a stage such as shown for Chrysemys. As a drawing of this model is not available, Mr. Oliver's excellent illustration of the Chrysemys model will adequately serve to elucidate the description for Chelydra.

The abducent group. The M. rectus lateralis (rect. lat.) has rotated in such a way that it lies approximately transverse to the long axis of the body, in a horizontal plane. It is the most slender of the eye muscles. Its laterally directed end narrows somewhat as it passes outward to become inserted on the posterior surface of the eye-ball in the equatorial region.

The M. retractor oculi (retr. oc.) is here a short massive muscle, lying upon the dorsal side of the M. rectus lateralis, and crossing it in an antero-lateral direction, so that an $\mathrm{x}$-shaped figure is formed. As it passes onto the eye-ball, which it reaches somewhat further mediad than the insertion of the M. rectus lateralis, a broad sheet of fibers pushes out from along the posteroventral border of the muscle and creeps antero-ventrally down over the surface of the eye-ball, towards the junction of the latter and the optic stalk. (In the embryo of Chrysemys this 
outgrowth has barely started and cannot be seen in the model). It is the further development of this sheet of muscle which results in the very broad median portion of the M. retractor oculi in the adult turtle, where it forms an extensive insertion, partially encircling the optic nerve at its entrance into the eye-ball.

As the two abducent muscles, in approaching their insertion, have so turned as to lie approximately transverse to their former direction; the abducent nerve reaches them at right angles to their long axes.s It enters the M. retractor oculi directly on its postero-ventral side. Immediately before penetrating this muscle, it gives off a large branch which follows closely the ventral surface of the M. retractor oculi, on its way to the M. rectus lateralis which it enters from the dorsal side at about the middle of its length.

In Chelydra at this stage a slender nerve comes from the trigeminal ganglion at the root of the nasociliary nerve, and penetrates the M. retractor oculi in a direct line with the ciliary ganglion. This evidently is the so-called long root of the ganglion. In the Chrysemys embryo in which it has already connected with the ganglion, it arises from the nasociliary nerve more distally (l.r.), and passes down between the Mm. rectus superior and retractor oculi, parallel to the N. oculomotorius.

The $M$. obliquus superior. This muscle (obl. sup.) has greatly increased in length. It is fixed at its insertion and is about to become fixed at its origin. Its former position corresponds with its inserted end, from which it extends ventrally and anteriorly, following closely the surface of the eye-ball. As it reaches the nasociliary nerve where this leaves the anterior surface of the eye, it makes a slight bend, passing dorsad of the nerve and continuing medially. In Chrysemys the muscle is less advanced and is shorter, but it has the same direction and position with regard to the eye-ball. The $\mathrm{N}$. trochlearis (n. troc.) has reached the M. obliquus superior a short distance from its insertion, penetrating its posterior edge.

The oculomotor group. The M. rectus superior (rect. sup.) has changed but slightly, having merely straightened somewhat, and grown further forward, and established its insertion. Its 
relation to the oculomotor nerve and ciliary ganglion remains the same. Its end of origin lies in close relation with the abducent museles. In sagittal sections the $\mathrm{Mm}$. rectus superior and retractor oculi are situated dorsally, forming respectively the anterior and posterior members of the group, and the M. rectus lateralis forms the ventral member.

The M. rectus medialis (rect. med.) is not soon separated from its twin muscle the M. rectus inferior (rect. inf.), and in the Chrysemys embryo there is still a slender convection between them. The M. rectus medialis has worked its way dorsally to become inserted on the antero-medial surface of the eye-ball. In the course of this migration the M. rectus inferior has been drawn anteriorly and lies close against the ventral surface of the optic stalk, below which it has found its insertion. The area of connection of the M. rectus inferior with the M. rectus medialis extends from about the middle of the medial side of the latter to its free end. The condition found in the Chelydra embryo shows that a like relationship of these muscles has existed, but the two muscles are now separatefrom each other. Evidently the M. rectus medialis, in growing forward toward its insertion, has drawn the free end of the M. rectus inferior further mediad and ventrad.

On the ventral surface of the M. rectus medialis, where it crosses the optic stalk, there is a small, globular, solid cell-mass (z) for which I am unable to account, unless it may be an accidentally separated portion of muscle or nerve tissue.

The M. obliquus inferior (obl. inf.) has effected its insertion in common with the M. rectus inferior, and has turned about its ventral end in a medial direction, following the change in position of the M. rectus medialis. It has now received its branch from the N. oculomotorius, the nerve entering on its posterior side, a short distance from the insertion.

In Chelydra the $\mathrm{Mm}$. recti medialis and inferior have just become separated, the separation having taken place at their free ends (origins). The M. rectus inferior has been drawn forward in this process, its end of origin having been moved from its proximity to the ciliary ganglion to a position ventral and 
anterior to the entrance of the optic stalk into the eye-ball. The inner ends of this muscle and the M. rectus medialis are therefore in close proximity. Together with the M. obliquus inferior they form a second group, at this stage, such that in sagittal sections the M. obliquus inferior is ventral and anterior, the M. rectus medialis dorsal and posterior, and the M. rectus inferior also dorsal and immediately posterior to the second.

With the exception of the M. retractor oculi which is more complex in form than the rest, the eye muscles have virtually attained their definitive positions, the establishing of their origins alone remaining.

The $M$. retractor oculi of the adult Chelydra is of great breadth and length as compared with the other eye muscles, and presents two divisions: a lateral (or external) portion, which arises from the base of the posterior edge of the interorbital septum; and a medial (or internal) portion, the origin of which extends from the origin of the lateral portion, forward, for some distance along the ventral margin of the interorbital septum. The medial portion is developed, as previously remarked, from the sheet-like down-growth of the posterior edge of the original muscle, and it is inserted along an area on the eye-ball partially surrounding the optic nerve. The lateral portion is narrower, and is inserted on the posterior surface of the eye mediad of the insertion of the slender M. rectus lateralis. In a lateral view of the eye, the M. rectus lateralis may be seen passing up dorsally along the posterior surface of the eye-ball and crossing the external portion of the M. retractor oculi.

The conditions in Chelydra are essentially as given by Bojanus for Testudo europaea, and by Hoffmann for other chelonian representatives.

\section{SUMMARY}

The head somites. In embryos of Chelydra serpentina, three prootic head somites are developed on each side.

The first head somite arises as a lateral outgrowth of entodermal cells from the antero-dorsal wall of the foregut. The outgrowing cells form a stalked, compact, and more or less irregu- 
lar mass on each side, in the interior of which cavities arise. These cavities coalesce, and eventually a large thin-walled vesicle is formed which reaches its maximum size at about the $9-\mathrm{mm}$. stage. A constant feature of the development of this somite is an extension from its ventro-lateral wall which enters into close temporary association with the developing musculature of the mandibular arch.

The area of outgrowing cells on the wall of the foregut, from which the first head somites are formed, very soon becomes differentiated into a thick-walled epithelial body with slit-like lumen - the so-called prechordal plate - which is connected laterally with the first head somites by a slender solid cell-stalk. The notochord ends anteriorly in the posterior wall of the plate.

As development proceeds, the cavity of the prechordal plate enlarges and its walls become thinner, as some of its cells pass over into the stalks of the somites. In some cases the cavities of the somites push into the stalks and connect with the cavity of the prechordal plate, thus forming a temporary connecting canal between the two somites. But in other instances the stalk of one or the other of the somites may become constricted off from the prechordal plate at a relatively early stage, and whether or not a cross-canal would in such cases be formed is difficult to say without more extensive study. In Chelydra the crosscanal, where found, is rather narrow. In some reptilian forms it is very broad. A part of the prechordal plate may remain attached to the end of the chorda and later become lost in the mesenchyma.

The second head somite. The seeond head somite arises in the dorsal mesoderm at the side of the neural tube, just below and slightly anterior to where the trigeminal ganglion later appears. It probably first appears as a small heap of concentrated mesodermal cells, but the early phase of this somite in Chelydra seems less clear than in Emys as described by Filatoff. These cells then become arranged in a radial manner about a central point or lumen, and assume the form of a small somite. The somite very soon becomes expanded into a thin-walled vesicle of more or less spherical form which may be accompanied by one 
or two much smaller vesicles. These may arise independently from smaller somite-like structures, as described in connection with the $3.5-\mathrm{mm}$. embryo, or by a budding-off process from the main cavity. The cells forming the wall of the vesicle or vesicles, constitute the somite. The vesicle reaches its maximum expansion at about the 5-mm. stage and may still be accompanied by a small number of minor cavities. A single main cavity is always present.

At this stage the ventral side of the somite is in close contact with an area of small cell-clusters and minute cavities, which have arisen in the mesoderm of the mandibular arch, just ventrad of the second head somite. They extend ventro-medially through the arch to the pericardial region, and form the anlage of the maxillo-mandibular musculature. From now on, the somite suffers a collapse of its walls and becomes broken down into a considerable number of smaller eavities, which in turn are reduced, until eventually but a mass of mesenchymal cells remains, scarcely distinguishable from the surrounding mesenchyma.

The third head somite, like the second, arises in the dorsal mesoderm close to the ventro-lateral side of the hind-brain, between the location of the facio-acustic and trigeminal ganglia, but nearer the latter. In an embryo of $3.5 \mathrm{~mm}$. the third head somite is a well differentiated structure with elear cut lumen and well defined epithelial walls; and it is slightly compressed, so that its principal axis is longitudinal. A little later this somite is subdivided, but at the stage under discussion, painstaking study of the sections, supplemented by a carefully made wax reconstruction failed to reveal any indication of subdivision. The subdivided condition, therefore, is to be considered as secondary, and results from the division of a primarily undivided somite.

The anterior division of the somite rapidly becomes expanded into a rather large vesicle, and for a time it may be connected with the second head cavity through a fusion of a part of their contiguous walls. The posterior portion is of considerably greater mass, has thicker walls and expands but slightly, so that its eavity is relatively small. It is connected for a short time with the eavity of the anterior division, and the walls of the two are 
continuous. In this condition (5-mm. stage) the position of the somite is such that the maxillo-mandibular division of the N. trigeminus passes across the mid-lateral wall of the somite and the vesicular anterior part lies in the angle formed by this nerve trunk and the ophthalmic division. The wall of the anterior division of the somite next collapses, and becomes transformed, in a manner similar to that of the second head somite, into a rather narrow mass of spindle-shaped cells which are continuous with the cells of the larger solid mass resulting from proliferation in the posterior division; so that two unequal masses are now formed, representing corresponding divisions of the somite. The anterior mass is the anlage of the M. rectus lateralis, and the posterior of the M. retractor oculi.

In regard to the idea expressed by some authors, that the head cavities form reservoirs for excretory products resulting from the activities of the developing somites, these observations on Chelydra can contribute nothing. The technique employed brought out no evidence that there is normally any substance present in these large cavities. In two instances, however, one of the first head somites was found gorged with blood cells. The first case occurred in an embryo Chrysemys marginata from the collection of Dr. B. M. Allen; the other in a $10-\mathrm{mm}$. Chelydra serpentina of the writer's series, in which the oculomotor muscles had begun to develop. Compared with the other side where conditions appeared normal, the eavity was more nearly spherical, but it was not appreciably larger, and no disturbance of the developing muscles had resulted. It could not be ascertained positively just where the contents had entered the cavity, but there were some indications that a rupture had oceurred in the ophthalmic artery, or perhaps in an adjacent part of the carotid artery itself.

The eye muscles. The first of the eye muscles to be laid down are those arising from the third head somite, or the abducent muscles. But these muscles, however, on account of the greater distance which they have to traverse in reaching their destination, are not the first to attain their adult position; the M. retractor oculi, due to its great complexity, is the last eye muscle to reach its definite position. 
When the third head somite has resolved itself into the two unequal but united portions above described, a gradual forward movement occurs. In this the posterior or retractor oculi portion plays the more conspicuous part, taking the lead and pushing its anterior end up along the median side of the M. rectus lateralis. The M. rectus lateralis portion, in the meantime, has become a more compact and better differentiated mass, in intimate association with the antero-ventral end of the M. retractor oculi. When the $11-\mathrm{mm}$. stage is reached the muscles form two separate and distinct masses of unequal size, lying just ventro-mediad of the ophthalmic division of the $\mathrm{N}$. trigeminus, near the posterior side of the ciliary ganglion. Their principal axes have changed from a horizontal direction to a more nearly dorsoventral one; and the M. rectus lateralis has also turned laterally towards its insertion on the posterior surface of the eye-ball. Its insertion is established in an embryo with a carapace length of $8.5 \mathrm{~mm}$. and after extending slightly towards its point of origin its final position is reached.

At this stage the posterior side of the M. retractor oculi has given rise to a broad sheet-like down-growth of fibers, the free edge of which grows along the surface of the eye towards the junction of the optic stalk and cup; this part becomes the medial division of this muscle as it occurs in the adult. The muscle then begins to grow posteriorly and medially towards its origin.

The abducent nerve first appeared in the $9-\mathrm{mm}$. stage. No connection with the abducent muscles can be made out until the $10-\mathrm{mm}$. stage. Here the nerve has penetrated the retractor portion of the muscle-mass. The abducent nerve arises from the brain by a number of very delicate rootlets, three of which can be counted in the $9-\mathrm{mm}$. stage; in an $11-\mathrm{mm}$. embryo six were found. In this stage the $\mathrm{M}$. rectus lateralis has received its nerve supply through a stout branch given off from the $\mathrm{N}$. abducens at the point where it enters the M. retractor oculi.

The $M$. obliquus superior. This muscle in Chelydra develops in precisely the same way as described by Filatoff for Emys lutaria, and the process accords with that observed in many other vertebrate forms. The muscle grows forward as a stream 
of cells from the dorsal portion of the mesenchymal cell-mass which results from the second head somite. It remains connected for a relatively long period with the ventral portion of the cellmass, and thereby attains great length. It passes forward over the dorsal side of the eye-ball, separates from the ventral part of the somite, and soon after the 11-mm. stage it becomes attached by its posterior end (insertion) at about the mid-dorsal surface of the eye, lying close to the surface of the latter along the equator. From this position the muscle gradually swings medioventrally, rotating about its inserted end, till it lies in a meridional direction $(8.5-\mathrm{mm}$. carapace stage) when it continues its growth directly towards its origin, passing just dorsad of the nasociliary nerve.

The N. trochlearis does not reach the M. obliquus superior until a comparatively late period-shortly after the $11-\mathrm{mm}$. stage. It enters the muscle near its insertion.

Filatoff states than in Emys the ventral portion of the second head somite, i.e., the cell-mass resulting from it, becomes a part of the musculature of the mandibular arch. Except for the small part of this mass which is directly adjacent to the musculature of the arch, I am inclined to believe that such is not the case in Chelydra. At least the evidence here gives little support to Filatoff's interpretation. The embryo of $8.5-\mathrm{mm}$. carapace showed no trace of this cell-mass and gave no clue to its probable fate. In younger stages its structure indicates that it is of muscle-forming nature but its progressive development seems interrupted or suppressed. As late as the 11-mm. stage it still remains unchanged in position and form, and its more lightly stained elements and open structure are in marked contrast with the heavily stained and dense masses of the maxillo-mandibular musculature, and with the progressive development characteristic of other muscle-masses. In view of these facts it seems that this part of the second head somite must be interpreted in some other way.

In elasmobranch embryos it was first shown by Miss Platt that from the ventro-median wall of the mandibular somite proper there is formed a muscle 'E,' which early reaches an ad- 
vanced development but thereupon degenerates and disappears. Lamb observed this muscle in Acanthias embryos, and in his illustrations its position and relations to the M. obliquus superior and the muscles of the mandibular arch, are strikingly similar to the conditions in Chelydra. It seems to me entirely probable that in the ventral portion of the second head somite of Chelydra we have the vestige of a muscle corresponding to this passing muscle appearing in elasmobranchs, the past functional significance of which is unknown.

The oculomotor muscles. The first muscle of this group to appear is the M. obliquus inferior. It begins at about the $9-\mathrm{mm}$. stage, as a somewhat loose outgrowth of cells from a rather small area on the outermost ventral portion of the wall of the first head somite, after the somite has reached its maximum expansion. The outgrowth is not in the nature of a true evagination of the wall, but irregular spaces from the somite cavity extend into its base. It takes a direction anteriorly and slightly ventrad towards the ventral surface of the eye-ball. By the $10-\mathrm{mm}$. stage it has become a solid club-shaped mass, the narrow proximal end of which still has a loose cellular connection with the somite wall. From this position it slowly moves forward along the medio-ventral surface of the eye-ball, and in a stage represented by an embryo of $8.5-\mathrm{mm}$. carapace length, the end which has become free from the somite wall becomes attached to the eye-ball, forming the insertion of the muscle; its opposite, anterior end has turned toward its attachment of origin. While it is the first of the oculomotor muscles to appear, it is the last to receive its nerve supply, and is preceded by the M. rectus superior in establishing its insertion.

The M. rectus superior arises soon after the M. obliquus inferior. Its anlage appears as a broad thickening of the posterior wall of the first head somite, near the dorsal side, extending from near its lateral end medially about three-fourths the width of the somite. Its outer posterior side is closely covered by the ciliary ganglion. From the beginning the position of this muscle is such that but a slight change in direction is necessary in reaching its definitive position. It bends antero-dorsally as it ap- 
proaches the eye-ball, along the surface of which it extends towards its insertion which it reaches quite simultaneously with the M. obliquus superior, in embryos of about $11 \mathrm{~mm}$. It then gradually straightens out, and grows directly towards its origin. The first branch developed from the oculomotor nerve goes to this muscle and is given off where the nerve crosses its dorsal posterior border to reach the ciliary ganglion.

The $\mathrm{Mm}$. rectus inferior and rectus medialis are the last of the eye muscles to begin their development, and they arise from a common anlage which is formed by a deep out-pocketing from the ventro-lateral wall of the first somite, just mediad of the M. obliquus inferior. This is the condition at the $10-\mathrm{mm}$. stage. A thickening of the walls of this out-pocketing, especially on the posterior and ventral sides, takes place simultaneously and it becomes transformed into a solid elongate mass. By the $11-\mathrm{mm}$. stage a constriction has appeared, slightly beyond the middle of this mass, differentiating it into a proximal M. rectus inferior and a distal M. rectus medialis. The distal end of the M. rectus inferior now lies where its insertion later occurs. The distal end of the M. rectus medialis swings gradually dorsalward in the direction of its future point of insertion on the eye-ball, in front of the optic stalk. Its proximal end, which at first is continuous with the distal end of the M. rectus inferior, works up along the medial side of this muscle so that the final separation of the two takes place at their proximal ends, i.e., their ends of origin. This has just occurred in the specimen with an $8.5-\mathrm{mm}$. carapace. Their insertions have by this time been established, and the muscles are directed toward their points of origin. In the $11-\mathrm{mm}$. stage each of these muscles has received its branch from the N. oculomotorius.

In regard to the origin of the abducent and oculomotor nerves Filatoff makes the following italicized statements:

Meiner Ansicht nach ist es von grosser Bedeutung, den ersten Zustand des Auftretens der Anlage, welche zwar keinerlei Nervenelemente enthält, doch in Form und Lage den künftigen Nerv präformiert, d.h. also den Umstand in Auge zu behalten, dass diese Anlage in innigstem und ununterbrochenen Zusammenhange mit der Anlage des Muskels 
steht und vom Nervensystem völlig unabhängig auftritt (p. 343, in regard to anlage of $\mathrm{N}$. abducens).

In der Entwicklungsgeschichte des Oculomotorius ist ebenso wie in der Abducens die Tatsache bemerkenswert dass die ursprüngliche Nervenanlage als unmittelbare Fortsetzung der Muskel-oder Somitenanlage dem Nervensystem nur angelagert ist und erst sekundär Beziehungen zu demselben durch die von dorther in die Anlage hinein wachsenden Nervenfasern gewinnt (p. 363).

The relation of the abducent nerve to the brain and to its muscles, at the time of its first appearance in Chelydra, has already been discussed. Contrary to Filatoff's opinion, the nerve does not arise in continuity with the developing muscles. Connection with the muscles is acquired later. Moreover, the abducent nerve is to be interpreted as formed by the direct outgrowth from the brain of several delicate filaments, which unite to form a bundle that is easily seen. In the early stages of Chelydra it is only on superficial examination that the filaments which connect this bundle with the brain may be overlooked.

Similarly the oculomotor nerve, when first found in the present study, had no connection with the first head somite, but could readily be followed to the brain tube. In the $10-\mathrm{mm}$. embryo, where the ciliary ganglion appears as an accumulation of cells at the distal end of this nerve, it still has no connection with its muscles. At $11 \mathrm{~mm}$., however, the nerve extends beyond the ventral border of its ganglion and connects with the Mm. recti superior, inferior and medialis. Later it connects with the M. obliquus inferior, and eventually it becomes separated from the ciliary ganglion except for a branch which forms the short root of the ganglion. Filatoff's conclusions, therefore, are not applicable to Chelydra.

\section{LITERATURE CITED}

Batfotr, F. M, 1878 Development of Elasmobranch fishes.

Bojanus, L. H. 1819 Anatome Testudinis Europaeae.

Braus, H. 1897 Beitrage zur Entwicklung des Muskel-und Peripheren Nervensystems der Selachier. Morph. Jahrb. Bd. 27.

Conning, H. K. 1900 Ueber die Entwicklung der Kopf-und Extremitäten Muskulatur bei Reptilien. Morph. Jahrb. Bd. 28. 
Frustofr, D. 1907 Die Metamerie des Kopfes von Emys lutaria. Morph. Jahrb. Bd. 37.

Hrul, Chartizs 1900 Developmental history of primary segments of vertebrate head. Zool. Jahrb., Anat. Abt. Bd. 13.

Hormanas, C. K. 1888 Reptilia, Bronn's Klassen und Ordnungen. Bd. 6., 3. ar Entwicklungsgeschichte der Selachii. Morph. Jahrb. Bd. 24 .

Johnston, J. B. 1905 The morphology of the vertebrate head, etc. Jour. Comp. Neur. vol. 15. 1906 Nervous system of vertebrates.

LAMB, A. B, 1901 Development of the eye-muscles in Acanthias. Amer. Jour. Anat., vol. 1.

Marshatl, A. M. 1881 Head cavities and nerves in Elasmobranchs. Quart. Jour. Micr. Sci.

Minot, C.S. 1901 On the morphology of the pineal region. Amer. Jour. Anat., vol. 1.

1910 Laboratory text book of embryology.

OPPEL, A. 1890 Ueber Vorderkopf Somite und die Kopfhöhle bei Anguis fragilis. Arch. f. mikr. Anat., Bd. 36.

ORR, H, 1887 A contribution to the morphology of the lizard. Jour. Morph., vol. 1.

Platt, Julia B. 1891 Contribution to the morphology of the vertebrate head. Jour. Morph., vol. 5.

1894 Ontogenetische Differenzirung des Ektoderms in Necturus. Arch f. mikr. Anat., Bd. 43 .

REUTER, K. 1897 Ueber die Entwicklung der Augenmuskeln beim Schwein. Anat. Hefte, Bd. 9.

Rex, H. 1900 Zur Entwicklung der Augenmuskeln der Ente. Arch f. mikr. Anat., Bd. 57. 1905 Ueber das Mesoderm des Vorderkopfes der Lachmöwe. Morph. Jahrb., Bd. 33 .

1911 Beitrage zur Entwicklung des Vorderkopfes der Vögel. Morph. Jahrb., Bd. 43.

Scammox, R. E. 1911 Normal plates on the development of Squalus acanthias. In Normentafeln z. Entwicklungsgeschỉchte d. Wirbeltiere, hrsg. von Keibel. XII.

Scort, W. B. and Osbors, H.F. 1879 On some points in the early development of the common newt. Quart. Jour. Micr. Sci.

Van B́mmmene, J. F. 1889 Ueber die Herkunft der Extremitäten- und Zungenmuskulatur bei Eidechsen. Anat. Anz., Bd. 4.

Vax Wishe, J. W. 1886 Ueber die Somiten und Nerven im Kopfe von Vögelund Reptilienembryonen. Zool. Anz., Bd. 9.

Znmmrmanx, K. W. 1899 Ueber Kopfhöhlenrudimente beim Menschen. Arch. f. mikr. Anat., Bd. 53. 


\section{ABBREVIATIONS}

aud, ear

ac. $X$, vagus secessory nerve

$b r$, brain

Ch., notochord

cil. g., ciliary ganglion

con. st., connecting-stalk of first head somites

div., diverticulum from ventro-lateral wall of first head somite

ec., ectoderm

f. ac., facio-acustic ganglion

F. B., forebrain

fg., foregut

$H$. B., hindbrain

hyo. cl, hyomandibular cleft

inf. + med. recti, inferior and medial $l$., lens recti muscles or their anlages

l. r., long root of ciliary ganglion

Man. V., mb. n. mandibular ramus of N. trigeminus

Max. V., maxillary ramus of N. trigeminus

max.-man., maxillo-mandibular musculature

mes., disintegrating portion of wall of first head somite

mus. 2, mus. 3 , musele anlages of gill arches

n. $a b d$. 2 , abducent branch to musculus rectus lateralis

N. $a b d$, ,

N. VI, $\}$ nervus abducens

$n a$, cil., nasociliary branch of nervus trigeminus n. oc., 1,2 , branches of nervus oculomotorius to eye muscles

$\left.\begin{array}{l}\text { N. oc., } \\ N . I I I,\end{array}\right\}$ nervus oculomotorius

$N$. troc., nervus trochlearis

obl. inf., musculus obliquus inferior

obl. sup., museulus obliquus superior

op. c., optic cup

op. st., optic stalk

Ophth. art., ophthalmic artery

Ophth. V, ophthalmic division of $\mathrm{N}$. trigeminus

pre., prechordal plate

rect. lat., musculus rectus lateralis

rect. inf., musculus rectus inferior

rect. med., musculus rectus medialis

rect. sup., musculus rectus superior

retr. oc., musculus retractor oculi

$S 1, S 2, S 3$, first, second and third head somites

S.C.N., short ciliary nerves

st., in model, remains of connectingstalk of first head somite

tri., nervus trigeminus

tri. g., trigeminal ganglion

$x$., ventral cell-mass of second head somite

$z$, cell-mass of doubtful significance and derivation.

$V 2+3$, maxillo-mandibular trunk of $\mathrm{N}$. trigeminus

$V I I$, nervus facialis

$I X$, nervus glossopharyngeus

$X$, nervus vagus 


\section{PLATE 1}

\section{EXPLANATION OF FIGURES}

$1 \quad 3.5-\mathrm{mm}$. Chelydra serpentina ( 10 segments). Section passing through head region. $\times 175$.

2 Same series. Section passing transversely through hindbrain vesicle. $\times 175$.

Same series. Section passing transversely through tip of forebrain. $\times 175$.

4 4-mm. Chelydra serpentina (13 segments). Sagittal section in median plane through prechordal plate. $\times 175$.

5 Same series. Sagittal section laterad of neural tube, through the N. trigeminus and second head somite. $\times 175$. 


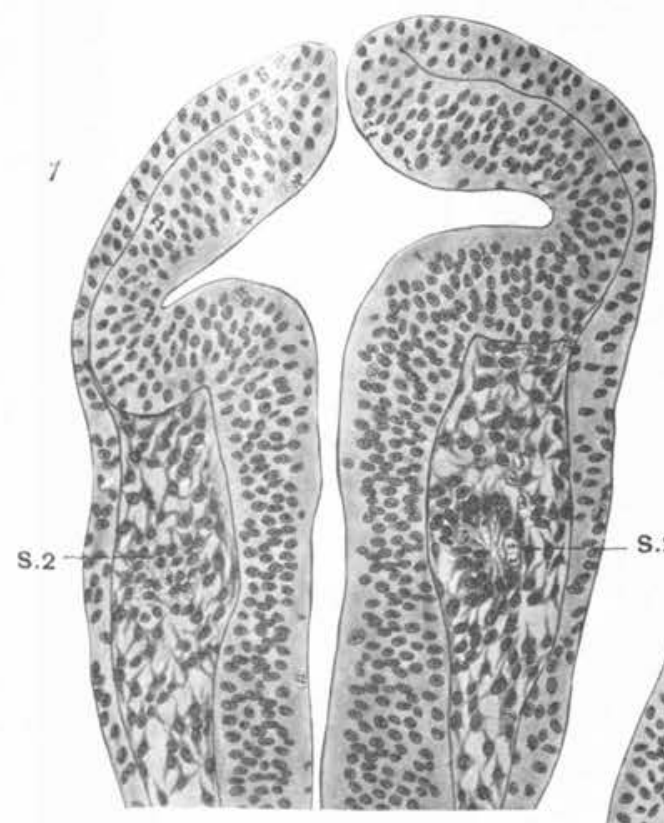

4

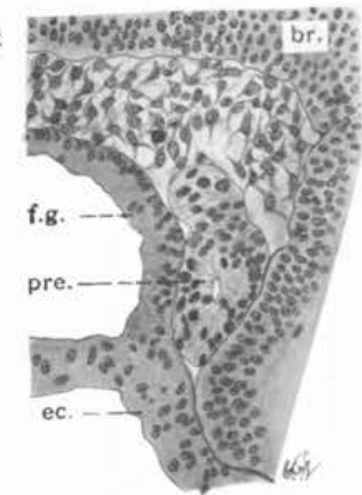

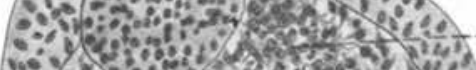
oriogies is 14ingosege

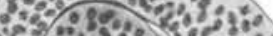

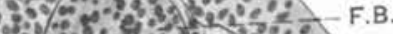

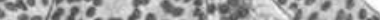
ind

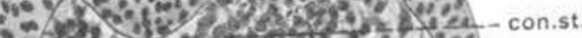

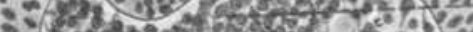
- conchos

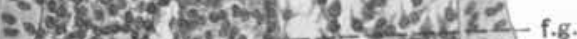

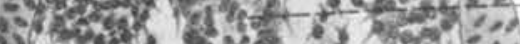

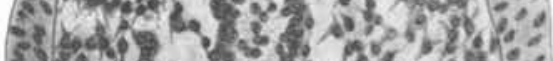

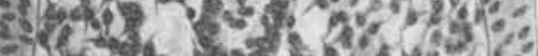

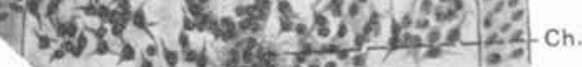

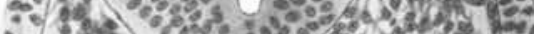

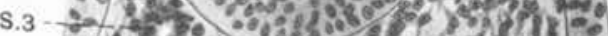

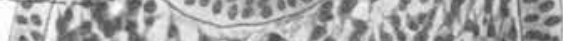

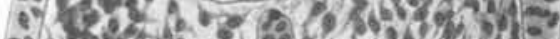

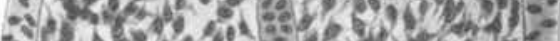

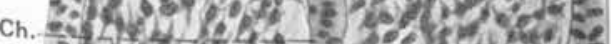

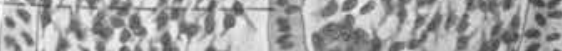
2)

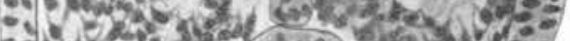

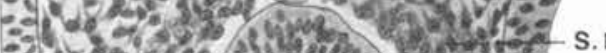
-3)

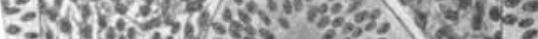

2<smiles>[14CH3][14CH3]</smiles>

$8.10 \%{ }^{\circ}$

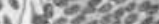

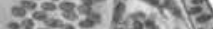

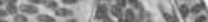

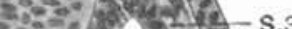

$\mathrm{S} .3$

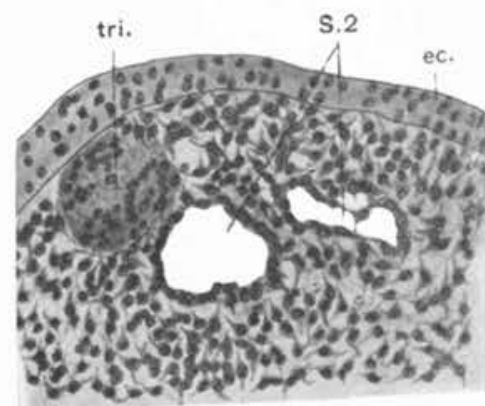

5 


\section{PLATE 2}

\section{EXPIANATION OF FIGURES}

6 4-mm. Chelydra (13 segments). Sagittal section somewhat further mediad figure 5, passing through third head somite. $\times 175$.

7 Sagitial section through third head somite of a second embryo Chelydra of $4 \mathrm{~mm} . \times 135$.

8 4.5-mm. Chelydra. Transverse section through the forebrain and first head somites. $\times 175$.

9 Section from same series, taken further anteriorly, passing through the antero-dorsal wall of foregut. $\times 175$.

$106-\mathrm{mm}$. Chelydra. Sagittal section through the mandibular arch, cutting outer edge of second head somite and the ventro-lateral divertieulum of first head somite. $\times 175$. 

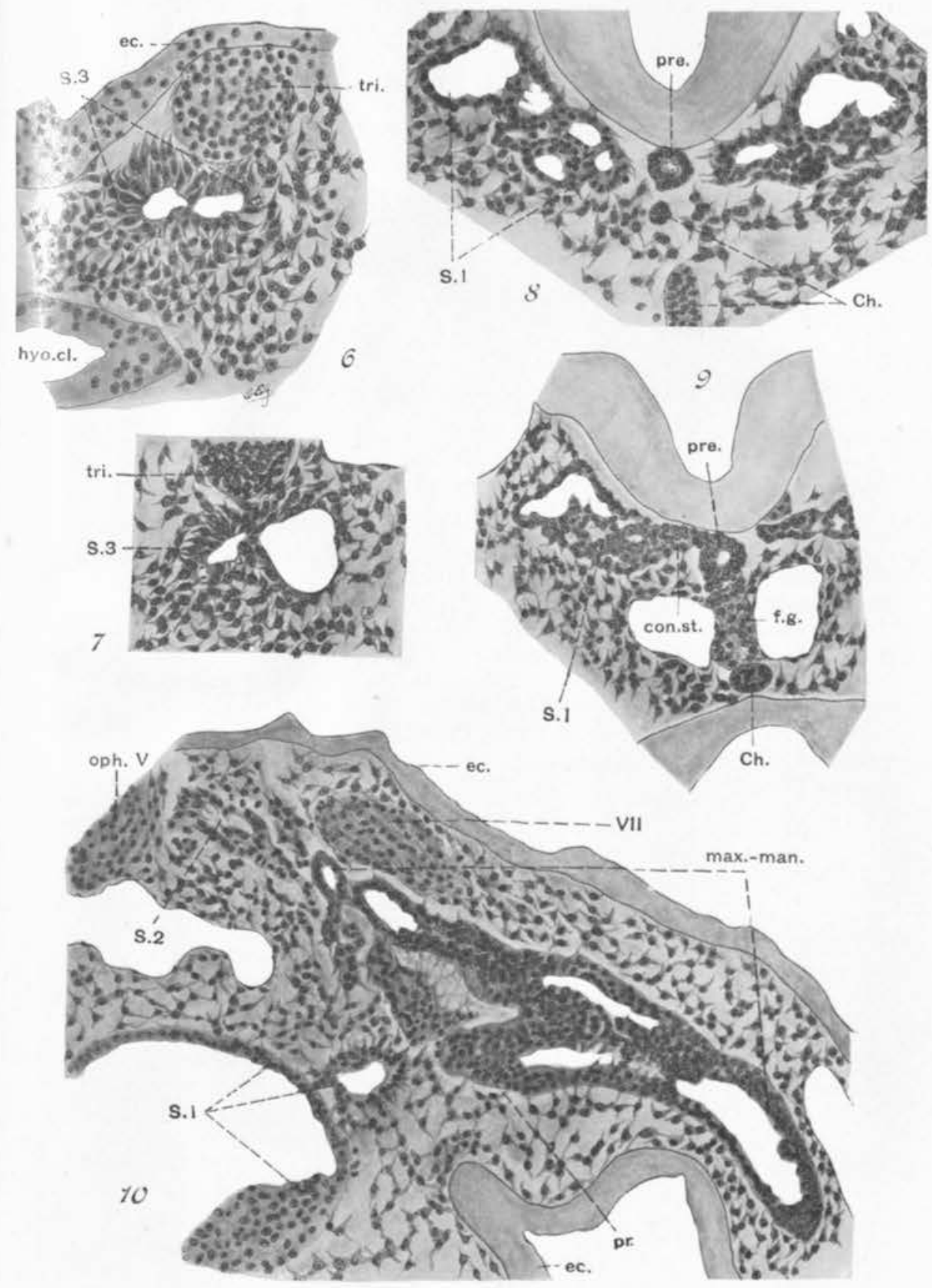


\section{PLATE 3}

\section{EXPLANATION OF FIGURES}

11 6-mm. Chelydra (second series). Sagittal section through second head somite and outer portion of abducent muscle-mass. $\times 175$.

12 Section from same series somewhat further mediad, passing through the two divisions of the abducent muscle-mass. $\times 175$.

13 9-mm. Chelydra. Sagittal section passing through outer wall of first head somite, showing the M. obliquus inferior. $\times 135$.

14 10-mm. Chelydra. Sagittal section through middle of first head somite and ganglion eiliare. $\times 135$. 

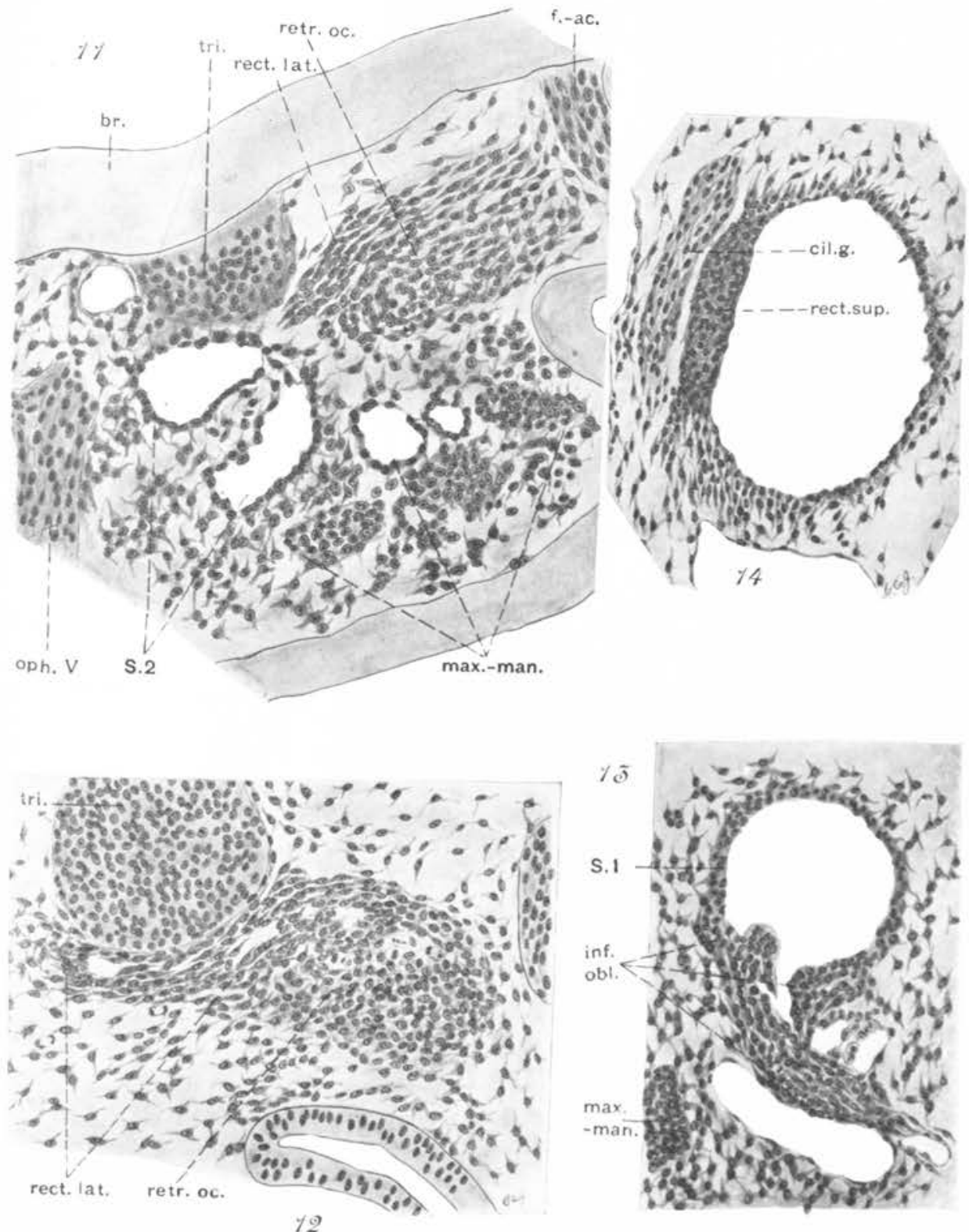
PLATE 4

EXPLANATION OF FIGURES

$1510-\mathrm{mm}$. Chelydra (same series as fig. 14). Sagittal section eutting lower edge of ganglion ciliare and the outer disintegrating wall of the first head somite. $\times 135$.

16 Same series. Section passing through the eye and the mandibular division of the trigeminal nerve. $\times 70$.

$17,1810-\mathrm{mm}$. and $11-\mathrm{mm}$. embryos respectively, showing the relations of the $\mathrm{Mm}$. rectus lateralis and retractor oculi. $\times 135$. 

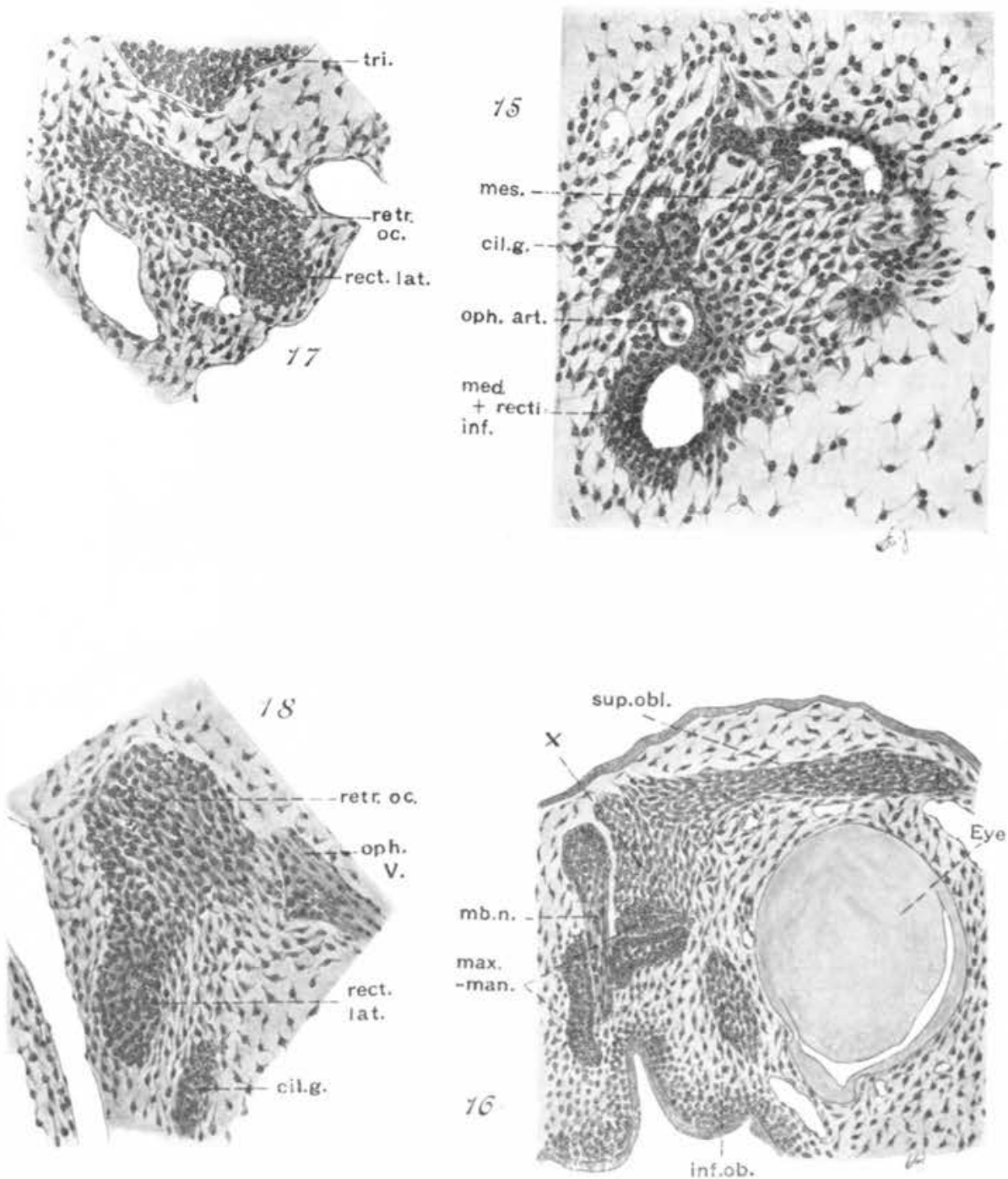
PLATE 5

EXPIANATION OF FIGURES

19 Wax plate reconstruction of right side of head of $5-\mathrm{mm}$. Chelydra serpentina. $\times 160$. 


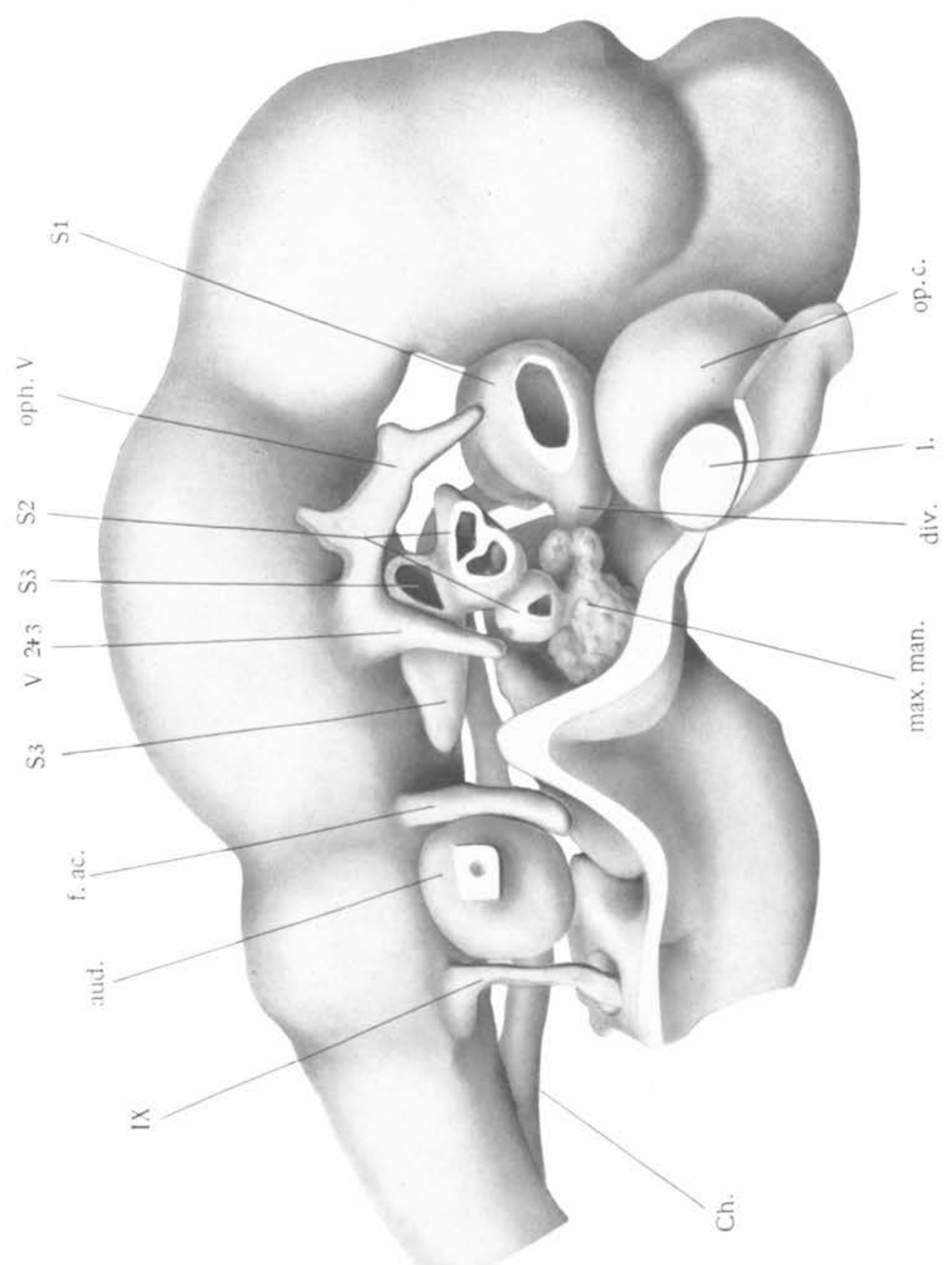


PLATE 6

EXPLANATION OF FIGURES

20 Wax plate reconstruction of right side of head of Chelydra embryo of $9-\mathrm{mm} . \times 80$. 


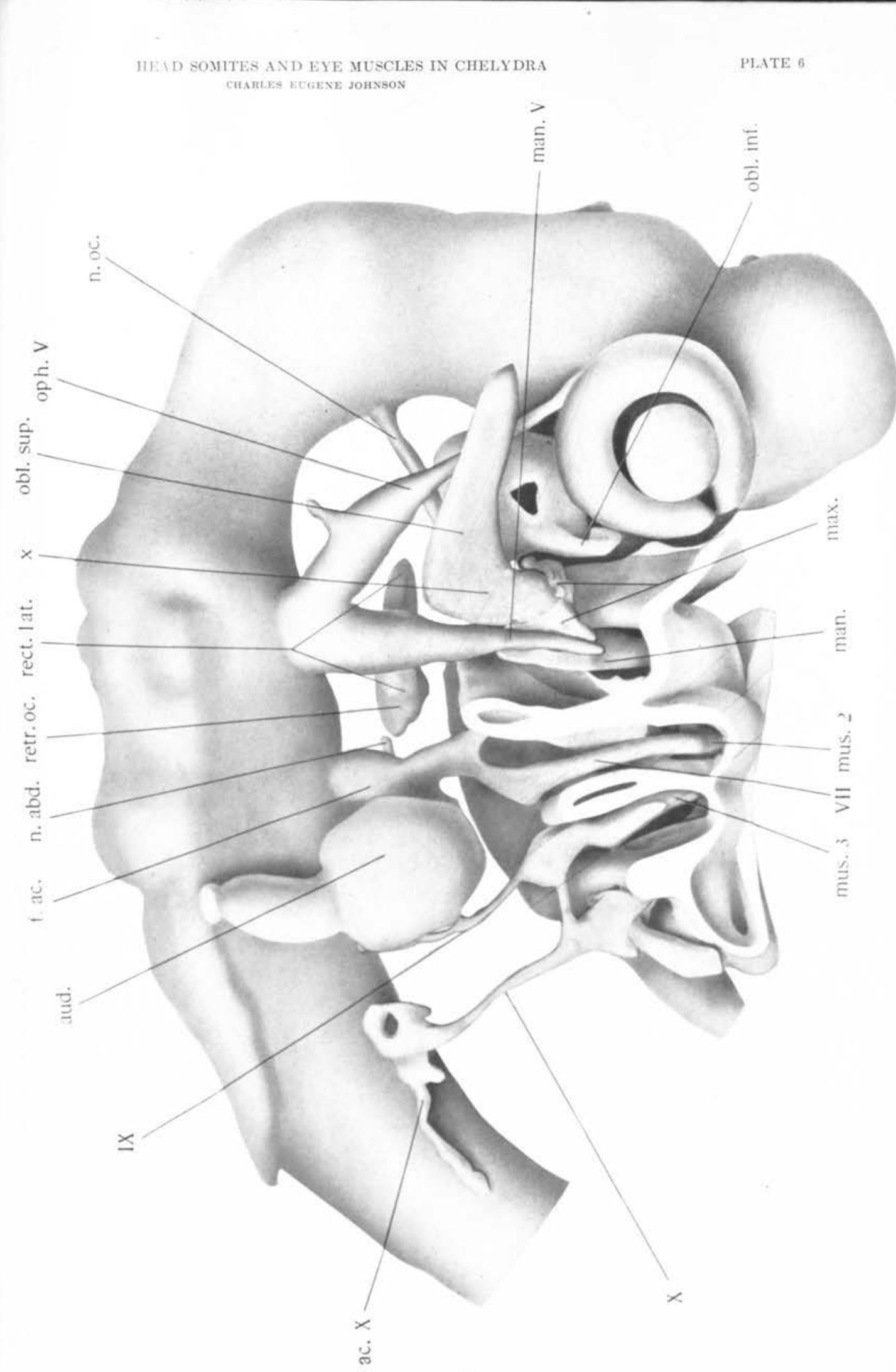


PLATE 7

EXPLANATION OF FIGURES

21 a Wax plate reconstruction of head of $10-\mathrm{mm}$. embryo Chelydra, showing head somites and developing eye muscles. $\times 50$. 


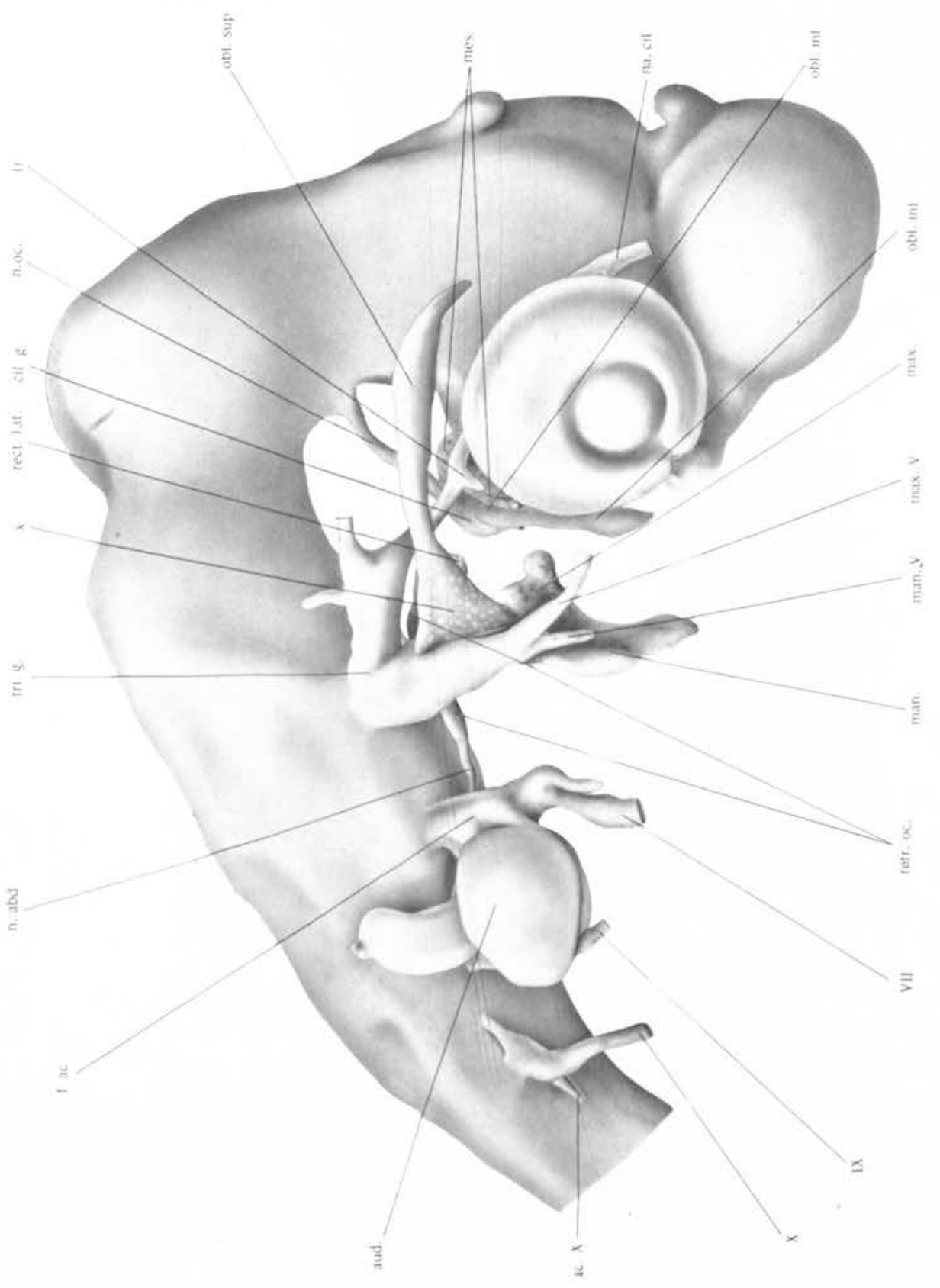

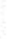




\section{PLATE 8}

EXPLANATION OF FIGURES

$21 \mathrm{~b}$ Wax plate reconstruction of the first and third head somites, with certain adjacent struetures, of the $10-\mathrm{mm}$. Chelydra shown in figure $21 \mathrm{a}$. Seen from the posterior side. $\times 100$. 


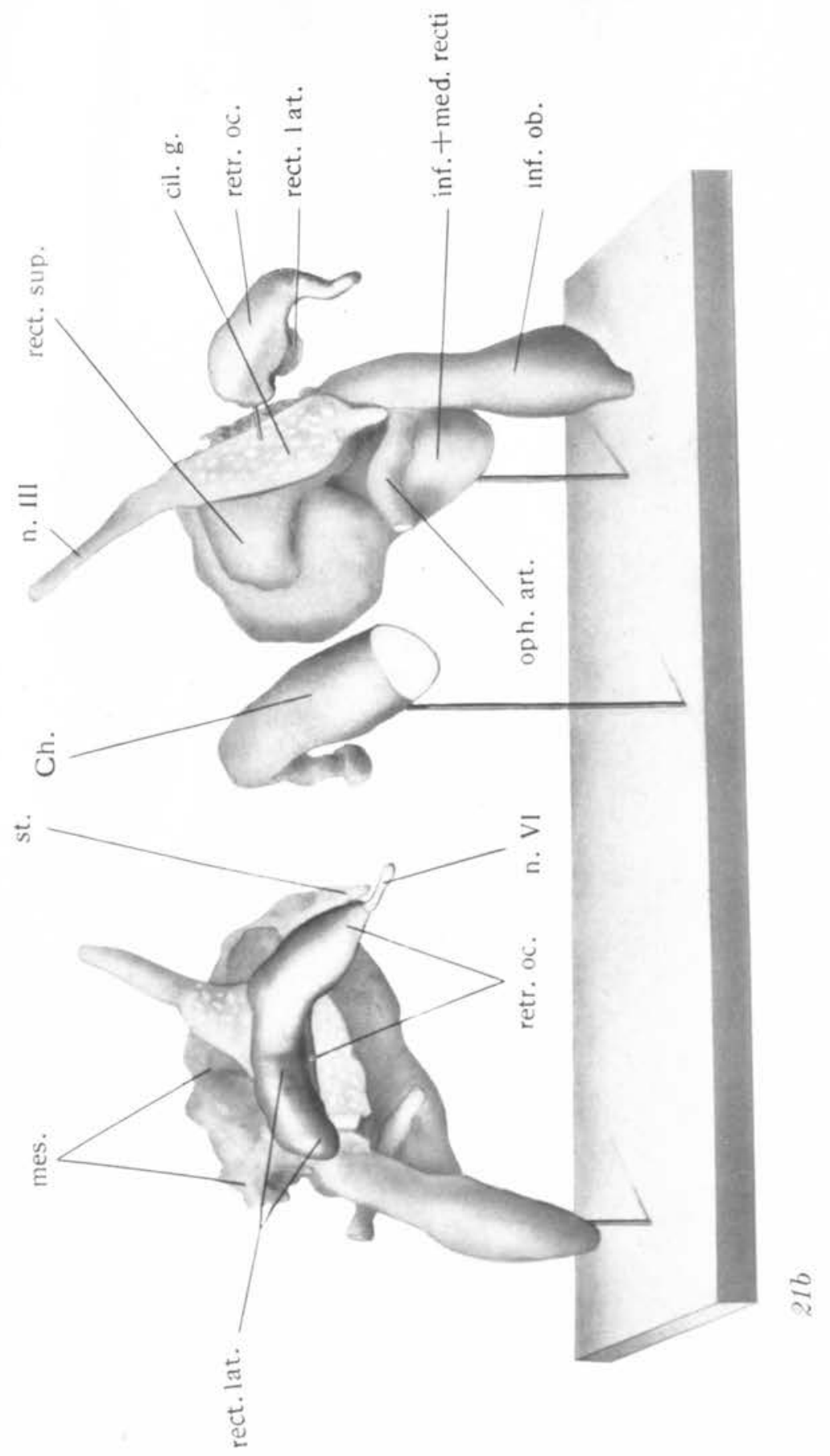




\section{PLATE 9}

\section{EXPLANATION OF FIGURES}

22 Wax plate reconstruction of the left eye-ball and adjacent structures of an embryo Chelydra of $11-\mathrm{mm}$. Seen from the median side. $\times 66$. On account of the cephalic flexure, when the embryo is in the upright position and viewed from the side, dorsal and ventral, in figures 22 and 23 , are as indicated on the plates, D.V. 
HEAD SUMTES AND FIE MUSCLES IN CHELYDRA

PIATE $\theta$

CHABt.ES LYTHSE JOHNSON

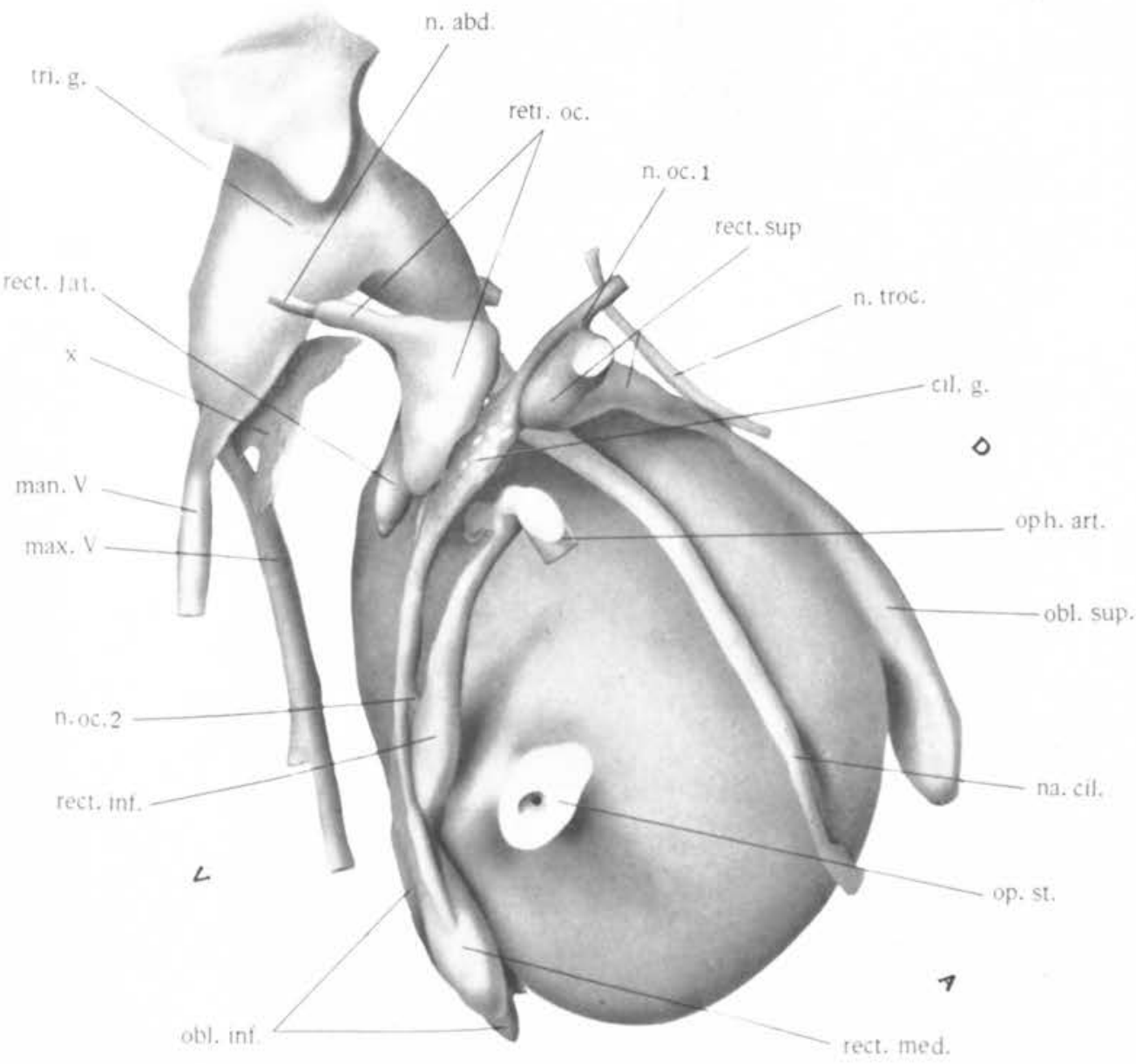

22 


\section{PLATE 10}

EXPLANATION OF FIGERES

23 Wax plate reconstruction of the right eye-ball and adjacent structures of an embryo Chrysemys marginata of $9 \mathrm{~mm}$., Harvard Embryological Collection, series 1085 . Seen from the median side. $\times 66$. 


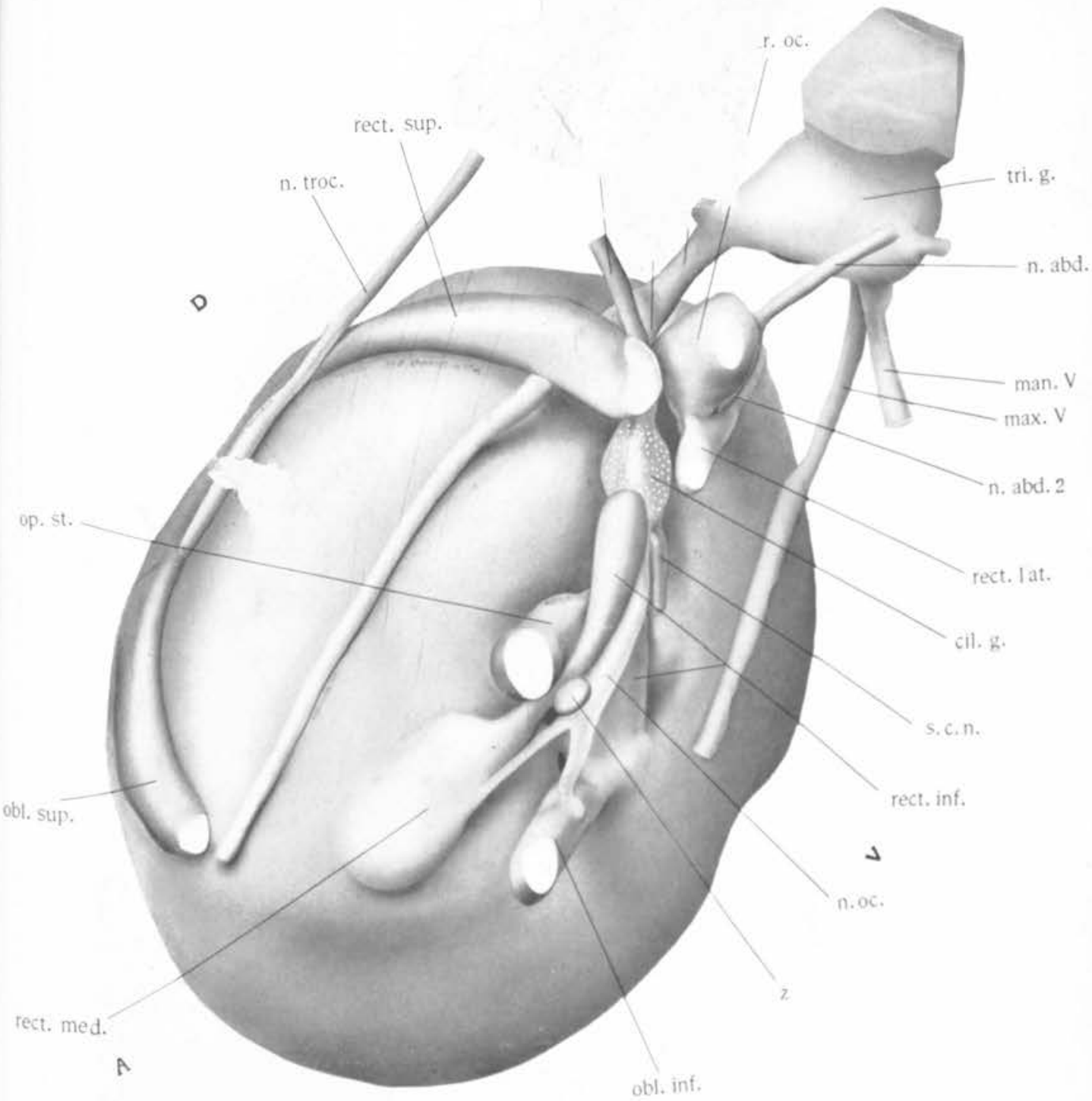

